January 2015

\title{
Probability, Confidence, and Twombly's Plausibility Standard
}

Luke Meier

Baylor Law School

\section{Recommended Citation}

Luke Meier, Probability, Confidence, and Twombly's Plausibility Standard, 68 SMU L. REV. 331 (2015)

https://scholar.smu.edu/smulr/vol68/iss2/3

This Article is brought to you for free and open access by the Law Journals at SMU Scholar. It has been accepted for inclusion in SMU Law Review by an authorized administrator of SMU Scholar. For more information, please visit http://digitalrepository.smu.edu. 


\title{
Probability, Confidence, And Twombly's Plausibility Standard
}

\author{
Luke Meier*
}

This Article offers a fresh perspective on the pleading standard of plausibility. The consensus regarding plausibility is that it requires a judge to determine the probability of the plaintiff's allegations. This perspective has led to much of the criticism of the plausibility standard. In reality, plausibility requires a judge to perform an analytically distinct inquiry, which I term a confidence analysis. Recognizing this fact does not immunize plausibility from all of the criticism it has received. It does, however, clarify the analysis required under the standard, which should alleviate many of the concerns associated with plausibility.

\section{TABLE OF CONTENTS}

I. FOUNDATION ............................... 336

A. Direct and Circumstantial Evidence.......... 336

B. Probability and Confidence .................. 340

II. Probability at the Pleadings Stage: PSLRA and the Seventh Amendment ............................. 345

III. CONFIDENCE AT THE PLEADINGS STAGE: $T W O M B L Y$ 'S PLAUSIBILITY STANDARD ........ 355

A. Either a Probability Analysis or a Confidence Analysis Can be Performed at the Pleadings

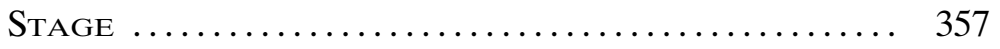

B. The Supreme Court's Use of the Word

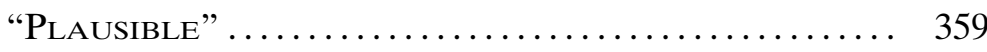

C. The Seventh Amendment.................... 370

D. The Policy Behind Twombly and the Transsubstantive Nature of the Federal Rules of Civil Procedure ........................ 372

IV. CONCLUSION: HOW A CONFIDENCE ANALYSIS COMPLIMENTS RULE 8'S FACTUAL SPECIFICITY REQUIREMENT.

* Associate Professor of Law, Baylor Law School. J.D., University of Texas School of Law. B.S., Kansas State University. This paper is part of a larger project that has benefited from the feedback of numerous individuals deserving of thanks: Kevin Clermont, Ken Klein, Jill Lens, Clyde Martin, Charles Nesson, Jerry Powell, Rory Ryan, Larry Solum, Jeff Stempel, Peter Tillers, Maggie Wittlin, Jim Wren, and Richard Wright. I am also grateful for the research help provided by the following individuals: Ryan Jamison, Erin Hamilton, Emily Oglesby, Andrea Palmer, and Kim Pearson. All errors are mine. 
$\mathrm{T}$

THE Supreme Court's decision in Bell Atlantic v. Twombly ${ }^{1}$ is not only one of the most cited Supreme Court cases ever decided, ${ }^{2}$ it is also one of the most misunderstood. The conventional wisdom regarding the "plausibility" standard introduced in Twombly is that this analysis dramatically alters federal pre-trial procedure and fundamentally changes the role and power of a federal judge at the pleadings stage of litigation. ${ }^{3}$ According to this view, Rule 8 of the Federal Rules of Civil Procedure now compels a judge to ascertain, for every civil case in federal court, whether the factual allegations of a complaint are sufficiently likely so as to survive a defendant's motion to dismiss. ${ }^{4}$

In a previous article, ${ }^{5}$ I dispelled one aspect of the conventional wisdom regarding Twombly: The notion that Twombly's plausibility analysis must be applied to every federal complaint is wrong. ${ }^{6}$ In reality, Twombly's plausibility standard applies only to complaints that have failed the factual specificity requirements of Rule $8 .^{7}$ This Article continues with the theme of my previous article, which is that Twombly has been misunderstood. Whereas my previous article addressed the question of when a plausibility analysis is necessary, this Article considers what type of analysis is expected under the plausibility standard.

The widely held view on this question is that the plausibility standard requires a judge to consider the likelihood of the facts asserted by the plaintiff. ${ }^{8}$ This perspective has been the impetus for some of the wide-

1. See generally Bell Atl. Corp. v. Twombly, 550 U.S. 544 (2007).

2. See Adam N. Steinman, The Pleading Problem, 62 Stan. L. Rev. 1293, 1295, 1357 (2010) (listing Twombly, as of March 17, 2010, as the seventh-most cited case of all time by federal courts and tribunals).

3. See Henry S. Noyes, The Rise of the Common Law of Federal Pleading: Iqbal, Twombly, and the Application of Judicial Experience, 56 ViLL. L. REV. 857, 858, 868 (2012) (explaining that Twombly "modified" the approach for determining whether a plaintiff has stated a claim under Rule 8); Edward D. Cavanagh, Making Sense of Twombly, 63 S.C. L. REv. 97, 98 (2011) (describing how Twombly "sent shockwaves throughout the federal civil justice system"); Paul D. Carrington \& Roger C. Cramton, Judicial Independence in Excess: Reviving the Judicial Duty of the Supreme Court, 94 Cornell L. Rev. 587, 629 (2009) (explaining how Twombly enlarges "the power of the district judge to enter judgment on the pleadings").

4. See Edward A. Hartnett, Taming Twombly: An Update After Matrixx, 75 Law \& Contemp. Probs. 37, 40 (2012) ("Some feared that the plausibility test would license judges to evaluate the believability of any (or all) allegations in a complaint.").

5. See generally Luke Meier, Why Twombly is Good Law (But Poorly Drafted) and Iqbal Will be Overturned, 87 IND. L.J. 709 (2012).

6. See id. at 711.

7. See id. ("[O]nly when the complaint has not been drafted with sufficient factual specificity does the plausibility analysis become necessary.").

8. See, e.g., Noyes, supra note 3, at 859 (stating that the plausibility standard "requires a district court to refer to objective information, albeit extraneous to the complaint, to inform itself of the 'truth' of the factual picture painted by the plaintiff in the complaint"); Rory Bahadur, The Scientific Impossibility of Plausibility, 90 Neb. L. Rev. 435, 456-57 (2011) ("The Court's use of the term 'possibility,' however, belies the assertion that plausibility is not a probability analysis because possibility is an expression of probability."); Suzette M. Malveaux, Front Loading And Heavy Lifting: How Pre-Dismissal Discovery Can Address the Detrimental Effect of Iqbal on Civil Rights Cases, 14 Lewis \& CLARK L. REv. 65, 83-84 (concluding that the plausibility test requires a probability 
spread scholarly backlash against the plausibility standard: how can a judge, based only on the allegations in a complaint, engage in an analysis of the likelihood of the facts in the plaintiff's complaint? ${ }^{9}$ Moreover, how is this procedure consistent with the Seventh Amendment's protection of a right to a jury trial in civil proceedings in federal courts? ${ }^{10}$

To appreciate why the conventional wisdom regarding the type of analysis required by the plausibility standard is wrong, and also to understand why some of the attacks against plausibility are misguided, it is necessary to distinguish between the concepts of probability and confidence. ${ }^{11}$ Stated simply, the concept of probability requires an estimate as to the likelihood of a given fact being true from a particular set of information; the confidence inquiry, on the other hand, asks how sure one can be in any probability estimate derived from incomplete information. ${ }^{12}$ Whereas a probability analysis requires a determination regarding what actually happened, a confidence analysis requires a conclusion as to whether there is a sufficient amount of information such that any probability estimate will be useful to the task at hand. ${ }^{13}$ As I have explained in a series of articles, distinguishing between these two concepts resolves a variety of procedural questions that have plagued federal courts and academic commentators for decades. ${ }^{14}$ Twombly's plausibility standard is simply the

analysis); Arthur R. Miller, From Conley to Twombly to Iqbal: A Double Play on the Federal Rules of Civil Procedure, 60 Duke L.J. 1, 26 (2010) (stating that the plausibility analysis depends "on the relative likelihood that legally actionable conduct occurred versus a hypothesized innocent explanation"); Marc I. Steinberg \& Diego E. Gomez-Cornejo, Blurring the Lines Between Pleading Doctrines: The Enhanced Rule 8(A)(2) Plausibility Pleading Standard Converges With the Heightened Fraud Pleading Standards Under Rule 9(B) and the PSLRA, 30 ReV. LiTig. 1, 26 (2010) (describing Twombly's plausibility standard as a "tacit" probability requirement).

9. See, e.g., Dawinder S. Sidhu, First Korematsu and now Ashcroft v. Iqbal: The Latest Chapter in the Wartime Supreme Court's Disregard for Claims of Discrimination, 58 Buff. L. Rev. 419, 489-90 (2010) ("Assessing which set of facts is more likely to be true is not, however, a proper function of a court at the motion to dismiss stage."); Allan R. Stein, Confining Iqbal, 45 Tulsa L. Rev. 277, 284 (2009) ("To allow a judge to make those determinations based on his own sense of history and human behavior without the benefit of an adversarial presentation of the facts is the precise definition of prejudice: he is pre-judging, without regard to the evidence.").

10. See, e.g., Kenneth S. Klein, Ashcroft v. Iqbal Crashes Rule 8 Pleading Standards on to Unconstitutional Shores, 88 NeB. L. Rev. 261, 262 (2009) (arguing that Iqbal "is unconstitutional when measured against the traditional . . . interpretation of the Seventh Amendment"); Suja A. Thomas, The New Summary Judgment Motion: The Motion to Dismiss Under Iqbal and Twombly, 14 Lewis \& CLARK L. Rev. 15, 38 (2010) ("[T]he Iqbal/ Twombly standard is unconstitutional.").

11. See Luke Meier, Probability, Confidence, and the Constitutionality of Summary Judgment, 42 Hastings Const. L.Q. 1, 2 (2014).

12. See Luke Meier, Probability, Confidence, and the Reasonable Jury Standard, 84 Miss. L. J. 747, 749-50 (2015).

13. See Meier, supra note 11 , at 1-2.

14. See Luke Meier, Probability, Confidence, and Matsushita: The Misunderstood Summary Judgment Revolution 23 J.L. \& PoL'y 69, 80 (2014) (explaining that the modern view of summary judgment, inspired in part by Matsushita, should be reexamined because Matsushita was decided under a confidence analysis rather than a probability analysis); Meier, supra note 11, at 1-3 (arguing that the contemporary debate regarding the constitutionality of summary judgment is misguided because it fails to appreciate the difference between probability and confidence). 
most recent example of the confusion that can arise when these two principles are not clearly distinguished and delineated.

Although the conventional wisdom is that Twombly's plausibility analysis involves a probability analysis, the better interpretation of plausibility is as a confidence analysis. According to the Court in Twombly, the plausibility standard "requires a complaint with enough factual matter (taken as true) to suggest that an agreement was made"15 but "does not impose a probability requirement at the pleading stage." ${ }^{16}$ As this language suggests, the critical issue in Twombly was not that the Court doubted the facts pleaded by the plaintiff. Instead, the Court was concerned that any conclusion from the scant facts asserted by the plaintiff would necessarily involve an impermissible amount of guess-work. ${ }^{17}$

Compelling reasons support the confidence interpretation of plausibility. ${ }^{18}$ For one, interpreting plausibility to mean confidence avoids the spirited Seventh Amendment objections that have been asserted against Twombly, most notably by Professor Suja Thomas. ${ }^{19}$ These Seventh Amendment objections all presuppose that the plausibility analysis requires a judge to engage in a probability analysis. ${ }^{20}$ Under a confidence analysis, however, a judge does not weigh in on the likely existence of the material facts to the litigation. ${ }^{21}$ Rather, under a confidence analysis, a judge makes a legal and policy determination about whether certain facts constitute a sufficient body of evidence from which to infer other facts. ${ }^{22}$ The Seventh Amendment does not preclude a judge from engaging in this confidence inquiry, even at the pleadings stage; English common law courts regularly engaged in this analysis at the time the Seventh Amendment was adopted in $1791 .^{23}$

Moreover, understanding plausibility to require a confidence inquiry aligns Twombly with the preeminent summary judgment case of Matsushita Electric Industrial Co. v. Zenith Radio Corp. ${ }^{24}$ Both the Matsushita and Twombly cases involved similar antitrust claims based on the defendants' purported (and illegal) business agreements, and both cases resulted

15. Twombly, 550 U.S. at 556 (emphasis added).

16. Id. (emphasis added).

17. Id. at $556-57$.

18. See Suja Thomas, Why the Motion to Dismiss is Now Unconstitutional, 92 Minn. L. Rev. 1851, 1853 (2008); Meier, supra note 11, at 71.

19. See Thomas, supra note 18, at 1853; Thomas, supra note 10, at 38; Klein, supra note 10 , at 262 (all arguing that Twombly requires a court to engage in an unconstitutional analysis).

20. See Thomas, supra note 18 , at 1852 (arguing that the plausibility standard eliminates the requirement that judges "take the alleged facts as true"); Klein, supra note 10, at 273 (implying that a probability analysis is required under the plausibility standard by stating that plausibility means "more than 'possibility' but something less than probability").

21. See Meier, supra note 11, at 3-4.

22. See id.

23. See id. at 70. (discussing the constitutionality of a judge dismissing a case, before a jury verdict, based on a confidence analysis).

24. See generally Matsushita Elec. Indus. Co. v. Zenith Radio Corp., 475 U.S. 574 (1986). See Meier, supra note 11, at 80. 
in a pre-jury judgment for the defendants. ${ }^{25}$ Because Matsushita was decided according to a confidence inquiry, ${ }^{26}$ it makes sense that the plausibility analysis in Twombly would involve the same inquiry.

The confidence principle can thus explain the relationship between the cases of Matsushita and Twombly. ${ }^{27}$ More importantly, however, the confidence principle also clarifies the broader relationship between summary judgment and the pleading standard of plausibility. ${ }^{28}$ Commentators have noted the relationship between plausibility and summary judgment, ${ }^{29}$ but a complete understanding of this connection has eluded commentators because the confidence principle has gone unidentified.

By understanding Twombly as a case in which plausibility was triggered by the lack of factual specificity in the complaint, and by recognizing that plausibility requires a judge to employ a confidence analysis, a clearer understanding emerges as to what transpired in Twombly. At the end of the day, plausibility might simply require a judge to answer the following question: if the plaintiff is able to assemble evidence of the real world events that are described (with sufficient factual specificity) in the complaint, would the plaintiff be entitled to proceed past the summary judgment stage to a jury trial? ? $^{30}$ If the answer to this question is "no," Twombly's holding can be understood as determining that there is no reason to delay this outcome. ${ }^{31}$ Properly understood, the logic and virtue of the plausibility analysis cannot be ignored, even if one ultimately disagrees with the merits of this procedural approach. ${ }^{32}$

25. See Matsushita, 475 U.S. at 576-82; Twombly, 550 U.S. at 548-53 (both dismissing, before trial, antitrust claims alleging illegal conspiracy).

26. See Meier, supra note 14, at 139 (explaining that Matsushita was decided accorded to an confidence theory).

27. See id.

28. See id.

29. See, e.g., Thomas, supra note 18, at 1857 ("In Twombly and Tellabs, the Court established standards for dismissal at the motion to dismiss stage that are similar to the standard for summary judgment.”); A. Benjamin Spencer, Plausibility Pleading, 49 B.C. L. REV. 431, 486 (2008) ("By requiring plaintiffs to offer factual allegations that report the factual basis for their assertions of liability and to do so in a way that makes liability plausible, the Twombly Court effectively has moved the summary judgment evaluation up to the pleading stage."); Richard A. Epstein, Bell Atlantic v. Twombly: How Motions to Dismiss Become (Disguised) Summary Judgments, 25 Wash. U. J.L. \& PoL'y 61, 81 (2007) ("[Twombly] should be framed as a mini-summary judgment case, conducted at the close of pleadings, and not as a pointless verbal disquisition on the contested meanings of 'plausible' and 'conceivable.' "); Kevin M. Clermont \& Stephen C. Yeazell, Inventing Tests, Destabilizing Systems 95 IowA L. Rev. 821, 849 (2010), at 833-34 n.47 ("[T]he TwomblyIqbal Courts seem to have collapsed the Rule 12(b)(6) and Rule 56 standards of convincingness into one.").

30. See Meier, supra note 11 , at 17 . This confidence analysis could be framed slightly differently; these variations are explored later in this article. See infra notes 116-19.

31. See Meier, supra note 11 , at 18.

32. To be sure, there are legitimate policy objections to this procedural approach, as it greatly undermines the importance of the discovery process. Commentators have pursued this objection with vigor. See Edward A. Hartnett, Taming Twombly, Even After Iqbal, 158 U. PA. L. REv. 473, 474 (2010) ("Scholarly reaction to Twombly has been largely critical, with most complaining that the Court imposed a heightened specificity standard of pleading and that plaintiffs will lack the evidence to plead these specifics prior to discovery."); see also Scott Dodson, Federal Pleading and State Presuit Discovery, 14 Lewis \& Clark L. 
The organization of this Article is as follows: Part I establishes a necessary framework for the remainder of this Article by briefly (1) discussing direct and circumstantial evidence and (2) delineating a probability analysis from a confidence analysis. Part II involves a slight detour to a discussion of the heightened pleading standard adopted by Congress in the Private Securities Litigation Reform Act (PSLRA). A discussion of the PSLRA pleading standard is important to understanding Twombly's plausibility standard. Both standards require a judge to make a determination about the relationship between (1) the facts pleaded by a plaintiff in her complaint and (2) the material facts necessary for a recovery. ${ }^{33}$ The PSLRA requires a probability analysis of this relationship, ${ }^{34}$ while Twombly's plausibility standard requires a confidence analysis of this relationship. Identifying the PSLRA as a probability pleading standard facilitates the recognition that Twombly's plausibility standard involves a different type of analysis. Part III demonstrates that the best interpretation of Twombly's plausibility standard is as a confidence, rather than a probability, analysis. Part IV concludes by linking the conclusion reached in this Article to that reached in my previous article regarding Twombly. What emerges is a logical procedural approach that is immune to much of the criticism that has been erroneously asserted against it.

\section{FOUNDATION}

In this section I will briefly discuss some introductory material, all of which I have more fully examined in other scholarship. A quick summary should provide the necessary foundation for the themes explored in the remainder of this Article. Those interested in a more thorough discussion of the issues identified in this section should consult my prior work. ${ }^{35}$

\section{A. Direct and Circumstantial Evidence}

Recognizing the distinction between circumstantial evidence and direct evidence is critical to the issues discussed herein. Direct evidence is evidence that, if believed by the fact-finder, directly proves a material fact to the litigation. ${ }^{36}$ Thus, if the dispositive question in a dispute is whether the southbound traffic light was green, testimony from an eyewitness that the light was green would constitute direct evidence of that material fact. ${ }^{37}$ If the witness is believed, the material fact has been resolved.

REv. 43, 44-45 (2010) (suggesting that presuit discovery may resolve the "catch-22" situation created by Twombly). My objective in this Article is not to take a position on these normative questions. Rather, the focus herein is descriptive.

33. 15 U.S.C. $\$ 78 \mathrm{u}-4$ (2012).

34. See Tellabs, Inc. v. Makor Issues \& Rights, Ltd., 551 U.S. 308, 313 (2007).

35. See Meier, supra note 11, at 37 (discussing the difference between direct and circumstantial evidence); id. at 17-18 (explaining a probability analysis and a confidence analysis).

36. See Meier, supra note 12 , at $753-54$.

37. See id. 
Direct evidence should be contrasted with circumstantial evidence. ${ }^{38}$ Circumstantial evidence is evidence of a fact from which the fact-finder might infer the existence of a material fact; ${ }^{39}$ we can refer to these as the "basic fact" and the "material fact." 40 Circumstantial evidence, then, requires an additional conclusion by the jury. First, the jury must believe the proponent's evidence that the basic fact exists. This process replicates the process involved with direct evidence. In addition, however, circumstantial evidence requires the jury to take the additional step of inferring the material fact from the basic fact. Thus, to prove that the southbound traffic light was green, a lawyer might introduce the testimony of an eyewitness who can testify that the eastbound traffic light was red. This requires, first, a determination that the witness is accurate with regard to his testimony regarding the eastbound traffic light. Second, a determination must be made regarding whether a southbound green light can be inferred from the existence of an eastbound red traffic light. This inference from basic fact (eastbound red light) to material fact (southbound green light) is the additional inference required from circumstantial, as opposed to direct, evidence. ${ }^{41}$

Of course, at the pleadings stage, neither party will have introduced any evidence into the case; at this stage of the litigation, the position of the parties is based on what is written in their respective pleadings. ${ }^{42}$ In this sense, it is somewhat misleading to use the terms direct and circumstantial evidence in discussing how a case should be treated at this early pleadings stage. Nevertheless, the difference between direct and circumstantial evidence is informative in considering the pleading requirement of plausibility because a party will draft her complaint differently depending on the type of evidence she has at the outset of the case. ${ }^{43} \mathrm{~A}$ party with direct evidence of a material fact will be able to draft the complaint with a certain level of factual specificity, providing the "who, what, and whens" of that material fact. ${ }^{44}$ On the other hand, a party without direct evidence of a material fact will describe why she believes that the material fact exists, and will thus plead circumstantial evidence in the complaint. ${ }^{45}$ In this sense, then, the manner in which the complaint is drafted

38. See id.

39. See id.

40. See id.

41. See id.

42. See Ronald J. Allen \& Alan E. Guy, Conley as a Special Case of Twombly and Iqbal: Exploring the Intersection of Evidence and Procedure and the Nature of Rules, 115 Penn St. L. Rev. 1, 28 n.137 (2010).

43. Cf. Louis Kaplow, Multistage Adjudication, 126 Harv. L. Rev. 1179, 1263 (2013) ("Put another way, what may appear to be courts' and commentators' fixation with precisely what is stated in a complaint, is in an important respect, an indirect way of addressing what evidence needs to be present [at the outset of the suit].").

44. Allen \& Guy, supra note 42 , at 41.

45. See id. Professor Kaplow has recently made the same general observation, although he fails to appreciate that when an event is described with factual specificity in a complaint an implicit assumption can be made that the plaintiff has direct evidence regarding that event: 
informs the judge as to what type of evidence-direct or circumstantialthe plaintiff has at the outset of the case.

The relationship between direct evidence, circumstantial evidence, and the style of a complaint is apparent in the now-familiar facts of Twombly. ${ }^{46}$ To recover in Twombly, the plaintiffs needed to show that the defendants had entered into an agreement not to compete with each other. ${ }^{47}$ The plaintiffs were not "sure," however, that the defendants had actually entered into such an agreement; the plaintiffs had no direct witness to this purported agreement. ${ }^{48}$ Obviously, though, the plaintiffs needed to allege an agreement for their complaint to state a cause of action. ${ }^{49}$ The plaintiffs could have made up facts to satisfy the factual specificity requirements of Rule 8 , but in doing so would have run afoul of the prohibitions in Rule $11 .^{50}$ Thus, the plaintiffs simply alleged the existence of the agreement without any factual specificity as to the details (who, what, when, etc.) of that agreement. ${ }^{51}$ The plaintiffs, however, intuitively understood that this generic assertion was not sufficient, and thus proceeded to explain why they felt justified in alleging the occurrence of the agreement. The plaintiffs thus alleged (with specific detail) the parallel business activities of the defendants, on the premise that this parallel

Insistence on a statement of facts (notably, regarding allegations in a complaint) does not in itself constitute a demand for evidence.

This conclusion, however, is substantially misleading-that is, as long as allegations based on pure fantasy are impermissible. Proffering a fact entails holding some basis for acceptance of the fact as true, which in turn requires possessing some evidence. Knowledge presupposes some evidentiary basis, information is tantamount to evidence, and belief in the truth of a fact presupposes evidence. As a consequence, although insistence on particular facts is not per se a demand for evidence, for all practical purposes it requires evidence.

Kaplow, supra note 43, at 1263.

46. Bell Atl. Corp. v. Twombly, 550 U.S. 544, 548-51 (2007).

47. Id. at 556 (explaining the agreement requirement).

48. Id. at 561-62.

49. Or, at least, the plaintiffs in Twombly believed that it was necessary to make this allegation to state a claim under Rule 8 . Whether a plaintiff must allege the facts that constitute a "cause of action" is a legal question that comes with heavy historical baggage. See generally 5 Charles Alan Wright \& Arthur R. Miller, Federal Practice and Procedure $\$ 1216$ (3d ed. 2015) (discussing that question); Meier, supra note 5, 721-27, 761-62 (arguing that the best understanding of the Federal Rules, as originally conceived, is that a plaintiff need not allege all of the facts that constitute a violation). My own sense of contemporary pleading practice, however, is consistent with what the plaintiffs in Twombly believed regarding pleading practice, which is that the plaintiffs needed to allege a conspiracy because conspiracy was an element of their claim. Indeed, the Court's decision in Twombly seems to assume this proposition; if the plaintiffs need not have alleged a conspiracy, then the Twombly decision would indeed be much ado about nothing. Nothing in the Twombly litigation, however, suggests that the plaintiffs' problems could have been avoided by simply amending the complaint and removing the (non-factually specific) allegation of an antitrust agreement.

50. See FeD. R. Civ. P. 11(b)(3) (explaining the requirement that the factual contentions in a complaint have evidentiary support).

51. See Consol. Amended Class Action Complaint at II 51, Twombly v. Bell Atl. Corp., 313 F. Supp. 2d 174 (S.D.N.Y. 2003) (No. 02 Civ. 10220), 2003 WL 25629874 ("Plaintiffs allege upon information and belief that [the defendants] have entered into a contract, combination or conspiracy. ..."). 
activity suggested the existence of an agreement between the defendants. ${ }^{52}$

As I have explained in my previous article, a complaint drafted with the requisite amount of factual specificity will not be subject to Twombly's plausibility analysis. ${ }^{53}$ Thus, when a plaintiff has direct evidence of the material facts to the case, the plaintiff will avoid Twombly's plausibility analysis because the direct evidence will allow the plaintiff to draft the complaint with the requisite amount of factual specificity. ${ }^{54}$ When the plaintiff does not have direct evidence at the outset of the litigation, the plaintiff will instead describe the circumstantial evidence that constitutes the impetus for the plaintiff's suit. ${ }^{55}$ In this scenario, Twombly's plausibility standard might be triggered. ${ }^{56}$

The distinction between direct and circumstantial evidence is thus critical in understanding Twombly's plausibility standard. Twombly will only be triggered when a complaint alleges circumstantial evidence-rather than a factually specific description - of a material fact. ${ }^{57}$ Moreover, the plausibility analysis requires a judge to consider this relationship between basic and material fact. ${ }^{58}$ Most commentators seem to appreciate that plausibility requires an examination of the relationship between basic and material fact, although this trait of the plausibility analysis is often as-

52. See id. (recounting the specific factual allegations regarding the defendants' parallel business conduct).

53. See Meier, supra note 5, at 728-33.

54. See id. at 730 .

55. See id. at 751 .

56. I say "might," here, because the inclusion of circumstantial evidence in a complaint should not necessarily trigger Twombly's plausibility analysis. As I have previously explained, a distinction must be made between facts that are capable of a factual description and those that are not. Twombly is an example of the former: The material fact in dispute concerned whether the defendants had formed an agreement. An agreement can only occur as the result of real-world interaction, and this real-world interaction can be described with factual specificity. Thus, for instance, the complaint in Twombly could have alleged that the Defendants had met at the Marriott Hotel in Waco, Texas, on February 6, 1996, at which point the Defendants entered into an agreement to refrain from competition. This hypothetical complaint would not have been subjected to Twombly's plausibility analysis; because the actual complaint in Twombly did not provide this factual specificity, however, the plausibility inquiry was triggered. This situation should be distinguished, however, from the complaint involved in Ashcroft v. Iqbal. The dispositive question in Iqbal concerned whether the defendants had acted with a discriminatory intent. This is a factual question, but it is not a factual question that is capable of a specific description. As such, the Court's conclusion in Iqbal to apply Twombly's plausibility standard was erroneous and a reflection of the Court's own internal confusion as to what had been decided in Twombly. See generally Meier, supra note 5, at 752-62.

To summarize, a complaint that is based exclusively on direct evidence will never be subject to Twombly's plausibility standard, but a complaint which relies on circumstantial evidence might—or might not-trigger plausibility. Asking whether a complaint has been drafted with factual specificity is not the same as asking whether the complaint relies on circumstantial allegations. It is the former, not the latter, which is controlling in determining when plausibility is triggered.

57. See Meier, supra note 5, at 751.

58. See id. at 753. 
sumed rather than explicitly identified.59 The more difficult question, though, is the nature of the judge's inquiry when considering the relationship between basic and material fact. This inquiry might involve two different analyses, which are explained below.

\section{B. Probability and Confidence}

The final foundational topic that needs to be addressed concerns the difference between a probability analysis and a confidence analysis. ${ }^{60}$ This distinction is critical yet somewhat elusive, particularly for those without formal mathematical training. Those readers who find the following cursory explanation of this distinction to be insufficient can find a more thorough examination in my previous work.

Both a probability analysis and a confidence analysis concern the relationship between facts, but each involves a completely different type of analysis of this relationship. The distinction between a probability analysis and a confidence analysis is perhaps best demonstrated by first showing how these distinct concepts might apply outside of the litigation context. A probability analysis is concerned with the likelihood or probability of a particular fact from a certain state of affairs. ${ }^{61}$ For instance, if the Kansas City Royals baseball team has played 100 games this season, and won 60 and lost 40, someone with this information (we will call him "George") might conclude that there is a $60 \%$ probability that the Royals will win their next game. This conclusion is based on a probability analysis. ${ }^{62}$ From a particular body of evidence or state of affairs (the Royals' win-loss record to that point in the season), a conclusion is reached regarding the probability of a particular fact (the Royals winning their next game). ${ }^{63}$

A confidence analysis, like a probability analysis, requires a determination regarding the relationship between a "state of affairs" or "evidence" and a particular fact. ${ }^{64}$ Under a confidence inquiry, however, this relationship is viewed from a different perspective. Whereas a probability analysis considers what the state of affairs indicates about the likelihood of a particular fact, a confidence analysis addresses whether the state of affairs is adequate such that there is a requisite degree of confidence in any probability assessment from the state of affairs. ${ }^{65}$ In the previous example, George concluded that the Royals had a $60 \%$ chance of winning their next game based on the team's win-loss record. George might also

59. See, e.g., William M. Janssen, Iqbal "Plausibility" in Pharmaceutical and Medical Device Litigation, 71 LA. L. Rev. 541, 554 (2011) (discussing the need to fill the "gap" of the conclusory allegations).

60. I have explored this distinction, in depth, elsewhere. See generally, Meier, supra note 12; Meier, supra note 11; Meier, supra note 14.

61. See id.

62. See Meier, supra note 11 , at $83-85$.

63. See id.

64. See Meier, supra note 12 , at $749-50$.

65. See id. 
conclude, however, that he wants additional information before wagering a bet with his friend that the Royals will win their next game. In other words, although George thinks that his probability estimate is accurate based on the limited information he has considered, he concludes that the amount of information he has considered is not adequate for the purpose of deciding whether to wager a bet with his friend or not. Before a wager is placed, additional information is desired, such as the Royals' opponent in the next game, the pitching matchup, the location of the game, etc. ${ }^{66}$

Whereas a probability analysis requires a somewhat mechanical analysis regarding the relationship between the state of affairs and a particular fact, a confidence analysis is more complex in that it requires an assessment of the purpose of any probability determination. ${ }^{67}$ In other words, a confidence analysis also considers the relationship between facts, but does so from the perspective of whether certain facts constitute a sufficient basis from which to make a conclusion regarding other facts. A confidence analysis, then, is ultimately a judgment about the adequacy of information, whereas a probability analysis is about the ultimate existence of facts. ${ }^{68}$ Thus, in the Royals example, whereas the process of determining the probability of a victory from the win-loss record could be statistically resolved, determining what to do with that probability conclusion required a more nuanced analysis that asked what the probability estimate was going to be used for. ${ }^{69}$ In the hypothetical, George was deciding whether to place a wager with a friend. Based on the limited information he had, ${ }^{70}$ a bet on the Royals was a good investment; according to the win-loss record, there was a $60 \%$ probability that the Royals would win. Nevertheless, the bet was refused. George's refusal to place the bet might be explained by a variety of logical justifications. George might feel that if he had more information about the pending game, the probability assessment of a Royals victory might change. ${ }^{71}$ For instance, if the Royals are playing against the best team in the league, and that team is starting its best pitcher, while the Royals are starting their worst pitcher, the probability of a Royals victory might change based on this additional information. Or, George might simply be risk averse. If the proposed bet is for George's last ten dollars, George might value retaining that ten dollars more than he values the opportunity to double that money, because the opportunity to double his money also involves the risk that he will go broke. Thus, even if the probabilities favor George, he might rationally conclude that he will not wager the bet. George's refusal to place the bet is not based on George's analysis of the likelihood of a Royal's victory, but rather on a more sophisticated conclusion that the amount of infor-

66. See id. at 795 .

67. See id. at 796 .

68. See id. at 750.

69. See id. at 795-96.

70. I am also assuming that the bet paid "even money," meaning each party to the bet was risking an equivalent amount.

71. See Meier, supra note 12, at 795-96. 
mation he has assembled is not sufficient for him to make a decision to bet. ${ }^{72}$ It is not that George necessarily thinks the Royals are likely to lose the following game, it is just that George has so little information that he does not feel confident enough in the $60 \%$ probability estimate to bet.

Turning from baseball to the litigation context, the distinction between probability and confidence is best illustrated by Professor Laurence Tribe's famous blue bus hypothetical:

Consider next the cases in which the identity of the responsible agent is in doubt. Plaintiff is negligently run down by a blue bus. The question is whether the bus belonged to the defendant. Plaintiff is prepared to prove that defendant operates four-fifths of all the blue buses in town. What effect, if any, should such proof be given? ${ }^{73}$

There is wide consensus that the blue bus hypothetical requires a judge-ordered judgment for the defendant. ${ }^{74}$ However, this conclusion (like George's refusal to bet on the Royals) cannot be understood from the perspective of probability because the limited, available information suggests that the defendant did, in fact, run over the plaintiff (just like the limited information suggests that the Royals would, in fact, win their upcoming game). ${ }^{75}$ The defendant's pre-jury victory in the blue bus hypothetical can only be explained through a confidence analysis. ${ }^{76}$ The critical issue in the blue bus hypothetical is not the ultimate probability that the defendant was the tortfeaser but rather the limited information available from which to make this probability determination. ${ }^{77}$ There is so little evidence available that there is an insufficient degree of confidence in the only probability conclusion that is reasonable from the record. ${ }^{78}$ The plaintiff has not satisfied her burden of production, not because we doubt the plaintiff's factual story, but because the plaintiff has failed to assemble a sufficient amount of evidence regarding the disputed question of fact. ${ }^{79}$

A different way in which to understand the confidence principle within the litigation context is through the old adage that "[a] brick is not a wall." 80 This familiar quote addresses the relevancy of evidence and nicely captures the liberal definition of relevancy contained within the modern Federal Rules of Evidence. ${ }^{81}$ In addressing the relevancy of par-

72. See id.

73. See Laurence H. Tribe, Trial by Mathematics: Precision and Ritual in the Legal Process, 84 HARv. L. Rev. 1329, 1340-41 \& n.37 (1971) (calling the blue bus hypothetical a "famous chestnut").

74. See Meier, supra note 12 , at 781-84.

75. See id. at 783.

76. See id. at 793-94.

77. See id. at 783-85.

78. See id.

79. See id.

80. MCCormick on Evidence § 185, at 339 (John William Strong ed., 4th ed. 1992).

81. See FED. R. Evid. 401 (articulating a broad standard for relevancy as any evidence having "any tendency to make a [material] fact more or less probable than it would be without the evidence"); see also Advisory Comm. Notes to Fed. R. Evid. 401 (citing the 
ticular pieces of evidence, however, the "brick is not a wall" adage does seem to presuppose that a wall might eventually be necessary. Thus, although an individual piece of evidence might be admissible under the Rules of Evidence as a single "brick," the confidence principle requires that the party with the burden of production (which is almost always the plaintiff) aggregate enough admissible "bricks" so as to amass at least a minimal "wall." Unless the plaintiff has assembled a bare minimum amount of information - that is, unless the plaintiff has compiled a minimum number of bricks - the plaintiff has not met her burden of production.

The nature of both the probability and confidence analyses determines how these tasks are divided between judge and jury. ${ }^{82}$ The nature of the confidence analysis requires that this task be assigned to the judge in the standard civil dispute. ${ }^{83}$ The confidence inquiry involves a determination as to how much of the potentially available information has been assembled in the case and also a determination as to the consequences of an incorrect conclusion. ${ }^{84}$ Both of these determinations are better resolved by a judge. ${ }^{85}$ In particular, the question regarding the consequences of an incorrect probability conclusion requires a policy or legal analysis that is simply beyond what can-and should - be expected of a civil jury. ${ }^{86}$ Only a judge can determine how "risk averse" a legal system should be regarding an inaccurate litigation conclusion in the standard civil context. ${ }^{87}$

The task of a jury in a civil dispute is to apply a probability analysis. ${ }^{88}$ This is evident from the jury instructions given to the jury in civil cases. ${ }^{89}$ The familiar "preponderance of the evidence" standard governing civil litigation instructs the jury that it must find for the plaintiff so long as it concludes that the facts alleged by the plaintiff are more probably true than not. ${ }^{90}$ The jury is thus to determine, from the evidence submitted at trial (the state of affairs), the likelihood of the facts alleged by the plaintiff. ${ }^{91}$ The jury is well-suited to perform this task. As discussed above, a probability analysis requires a somewhat mechanical analysis of the relationship between the evidence submitted at trial and the material facts to the dispute. For direct evidence, this requires an assessment of the credibility of the trial witnesses; for circumstantial evidence, the jury must re-

"brick is not a wall" concept as exemplifying the broad approach to relevancy contained in Rule 401).

82. See Meier, supra note 12 , at 797-98.

83. See id. at 798.

84. See id. at 799.

85. See id. at 805.

86. See id. at 806.

87. See id.

88. See id. at 807.

89. See id. at 761-62.

90. See Vern R. Walker, Preponderance, Probability and Warranted Factfinding, 62 BRoOK. L. Rev. 1075, 1076 n.5 (listing commentators (and judicial opinions) that associate the preponderance of the evidence standard with fifty percent probability).

91. See Meier, supra note 12, at 772. 
solve the relationship between the basic facts and the material facts. ${ }^{92}$ In either instance, the jury's real-world experiences are invaluable in performing this probability analysis. ${ }^{93}$

After the Supreme Court's decision in Anderson v. Liberty Lobby, Inc. ${ }^{94}$ however, federal courts - in addition to the jury-are also charged with employing a probability analysis. Under the "reasonable jury" standard for summary judgment adopted in Anderson, a judge is to determine whether a reasonable jury could come to only one conclusion as to the probability of the material facts in dispute. ${ }^{95}$ A judge cannot determine what a reasonable jury could conclude regarding probability without independently examining the evidentiary record and engaging in a probability analysis. ${ }^{96}$ Granted, the nature of the trial judge's probability analysis is somewhat deferential; theoretically speaking, the trial judge is not making a final conclusion with regard to probability but only determining whether the range of reasonable probability conclusions from the evidentiary record includes resolutions favoring both the plaintiff and the defendant. ${ }^{97}$ That said, although the judge's analysis of probability at summary judgment is less exacting and somewhat deferential, the judge is nevertheless engaged in a probability analysis. ${ }^{98}$

Thus, under modern federal civil procedure, a judge is expected to perform both a confidence analysis and a probability analysis at the pre-trial stage of a dispute. ${ }^{99}$ By introducing the plausibility standard in Twombly, the Court might have been referring to either of these analyses. The Twombly plausibility standard clearly requires an analysis between the circumstantial "evidence" or facts pleaded by the plaintiff and the ultimate or material fact necessary for the plaintiff's recovery. ${ }^{100}$ Both a probability analysis and a confidence analysis perform this function. So, which did the Court intend in Twombly?

Before directly addressing that question, this Article will first consider the pleading standard adopted in the Private Securities Litigation Reform $\mathrm{Act}^{101}$ (PSLRA). In the PSLRA, Congress clearly intended for courts to engage in a probability analysis at the pleadings stage. ${ }^{102}$ The PSLRA is thus an example of how a probability standard can function at the pleading stage, and therefore provides an excellent launching point from which to consider Twombly's plausibility standard. The PSLRA also illustrates

92. See Meier, supra note 12 , at 753-54.

93. See Paul F. Kirgis, The Problem of the Expert Juror, 75 Temp. L. Rev. 493, 520

(2002) ("We value juries precisely because they bring real-world experience to bear ....").

94. See generally Anderson v. Liberty Lobby, Inc., 477 U.S. 242 (1986).

95. Id. at 250-51.

96. See Meier, supra note 12 , at 766-67.

97. Id. at 773 .

98. See id.

99. After the trial has commenced, a party may move for a judgment as a matter of law under Rule 50, which explicitly references the reasonable jury standard (unlike Rule 56). See FED. R. CIV. P. 50.

100. See Bell Atl. Corp. v. Twombly, 550 U.S. 544, 553 (2007).

101. 15 U.S.C. \& 78u-4 (2012).

102. See supra notes 57-60 and accompanying text. 
the constitutional concerns that arise by permitting a judge to engage in a probability analysis at the pleadings stage, even if these Seventh Amendment objections were not taken seriously in the Court's decision in Tellabs Inc. v. Makor Issues \& Rights, Ltd. ${ }^{103}$

\section{PROBABILITY AT THE PLEADINGS STAGE: PSLRA AND THE SEVENTH AMENDMENT}

In 1995, Congress enacted the PSLRA "[a]s a check against abusive litigation by private parties"104 alleging violations of federal securities laws. Towards this goal, the PSLRA altered, for securities fraud claims under $\S 10(\mathrm{~b})$ of the Securities Exchange Act of 1934, ${ }^{105}$ the usual pleading requirements of the Federal Rules of Civil Procedure. ${ }^{106}$ In order to recover on a $\S 10$ (b) claim, a plaintiff must show that the defendant acted with "scienter," which occurs when the defendant had an "intent to deceive, manipulate, or defaud." 107 Under the PSLRA pleading standard, a plaintiff must "state with particularity facts giving rise to a strong inference that the defendant acted with the required state of mind." 108

There are three components of this pleading requirement. First, in addition to requiring that the plaintiff plead the defendant's state of mind, the plaintiff must plead the facts the plaintiff believes support the plaintiff's conclusion regarding the defendant's state of mind. Obviously, the defendant's state of mind is not an event or occurrence that the plaintiff (or any witness) will ever have been able to observe firsthand. ${ }^{109}$ In this respect, the factual question of a party's intent will always be different than the factual question of a real world event such as, for instance, a car crash. It is possible to have witnesses who directly observed the car crash and who will be able to describe this event with great particularity. It is impossible to have "witnesses" who observed a party's state of mind, with the exception of the party himself or herself. ${ }^{110}$ In any event, this require-

103. 551 U.S. 308, 326-27 (2007).

104. Id. at 313 .

105. 15 U.S.C. $\$ 78 \mathrm{j}(\mathrm{b})(2012)$.

106. See Tellabs, 551 U.S. at 319-22 (describing how the PSLRA amends the Federal Rules).

107. Ernst \& Ernst v. Hochfelder, 425 U.S. 185, 193 (1976). The Supreme Court has not answered the question whether reckless behavior, as opposed to intentional deceit, is sufficient for establishing liability under $\S 10(\mathrm{~b})$. See Tellabs, 551 U.S. at 319 n.3.

108. 15 U.S.C. $\$ 78 u-4(b)(2)(A)$.

109. See Meier, supra note 5, at 756 ("A person's state of mind . . cannot be described any more specifically . . . other than to say that the state of mind does, or does not, exist.").

110. At a deep level, even when the party whose intent is in question indicates that he does, in fact, have the requisite intent through some sort of "smoking gun" admission or communication, this observation is different than when a witness observes a real world event. The party who says that he has that intent (for instance, an executive at a publicly traded company who writes an internal email explaining that his public statement was intended to defraud the public) has not really "observed" that "fact" in the same way that a witness can observe a car crash. $C f$. René Descartes, Principles of Philosophy (1644) ("[C]ogito, ergo sum ...."). Despite this complexity, this sort of "smoking gun" evidence is often referred to as direct, rather than circumstantial, evidence, and this characterization makes some sense. See Anne Lawton, The Meritocracy Myth and the Illusion of Equal 
ment of the PSLRA does not change the operative standard under Federal Rule 9(b), which requires that "the circumstances constituting fraud" be pleaded. ${ }^{111}$

The second component of the PSLRA pleading requirement is that the facts supporting the plaintiff's conclusion of scienter must be pled "with particularity." 112 Here again, this standard traces the heightened pleading standard of Rule 9(b), which requires that a plaintiff "state with particularity the circumstances constituting fraud or mistake." 113 Note, however, that the particularity requirement (in both the PSLRA and Rule 9(b)) does not (and cannot) apply to the ultimate question of the defendant's scienter. As explained above, this fact is incapable of either direct observation or a specific, factual description.

The PSLRA departs from the Federal Rules, however, in the third component of the pleading requirement it establishes. The plaintiff's particularly pleaded facts must give rise "to a strong inference that the defendant acted with the required state of mind." 114 There is no doubt that this language requires a judge to do a probability analysis at the pleadings stage. Indeed, this point is conceded in the Tellabs, Inc. v. Makor Issues \& Rights, Ltd. decision interpreting the PSLRA.115 In Tellabs, the Court assumes that the PSLRA requires a judge to perform a probability analysis, and the only question is the degree of probability that must be established by the plaintiff. ${ }^{116}$ On this question, the Court resolved that the plaintiff "must plead facts rendering an inference of scienter at least as likely as any plausible opposing inference."117 The standard applied by

Employment Opportunity, 85 MinN. L. REv. 587, 614 n.133 (2000) (listing cases discussing "direct evidence" in discrimination cases).

111. FED. R. Civ. P. 9(b). For cases not involving "fraud or mistake," however, and thus governed under the generic pleading requirements of Rule 8, I have argued that the likely intent of the drafters of the Federal Rules was that a plaintiff need not even allege a defendant's state of mind because this "fact" was not an observable, real world event (unlike, for instance, the question of whether the light was green or red). See Meier, supra note 5, at 761-62.

112. 15 U.S.C. $\$ 78 \mathrm{u}-4(\mathrm{~b})(2)(\mathrm{A})$.

113. FED. R. CIV. P. 9(b).

114. 15 U.S.C. $\S 78 u-4(b)(2)(A)$ (emphasis added).

115. See Tellabs, Inc. v. Makor Issues \& Rights, Ltd., 551 U.S. 308, 314 (2007).

116. See id. (describing the issue being decided in Tellabs).

117. Id. at 328. In different portions of the opinion, the Court articulates the standard slightly differently. See id. at 314 ("[A]n inference of scienter . . . must be cogent and at least as compelling as any opposing inference ...."); id. at 324 ("A complaint will survive, we hold, only if a reasonable person would deem the inference of scienter cogent and at least as compelling as any opposing inference one could draw from the facts. ..."); id. at 326 ("[T]he reviewing court must ask: When the allegations are accepted as true and taken collectively, would a reasonable person deem the inference of scienter at least as strong as any opposing inference?"). These discrepancies in describing the applicable standards are sloppy and somewhat maddening. See Stephen Burbank, Pleading and the Dilemmas of "General Rules", 2009 Wis. L. REV. 535, 538-39 (2009) (stating that the Court's opinion in Tellabs "is hardly a model of precision or consistency in the use of language" and is an example of what occurs when a writer is concerned with "expressing themselves prettily [rather than] clearly"). The word "cogent" appears in some articulations but not all, as does the phrase "reasonable person." Each phrase creates some ambiguity regarding the underlying test. 
Professor Geoffrey Miller has addressed both of these ambiguities in his recent article, $A$ Modest Proposal for Securities Fraud Pleading After Tellabs, 75 Law \& ContemP. Probs. 93 (2012). With regard to the "cogent" language, Professor Miller concludes that this language should be essentially ignored; although the "cogent" language creates a colorable argument that the statute compels a court to compare the plaintiff's version of the facts with the defendant's specific versions of the facts, Miller concludes that the true test requires a comparison of the plaintiff's version of the facts (scienter) versus all other explanations (no scienter). See id. at 94-96; cf. Michael S. Pardo \& Ronald J. Allen, Juridical Proof and the Best Explanation, 27 LAW \& PHIL. 223, 234-35 (2008) (discussing an "inference to the best explanation" approach to the jury's burden of persuasion).

The inclusion of the "reasonable person" phrase in some (but not all) versions of the Court's articulation of the PSLRA standard is, perhaps, even more problematic than the "cogent" language. See Tellabs, 551 U.S. at 324, 326 (stating test with "reasonable person" language included); $i d$. at 314 (stating the test without the "reasonable person" language). The "reasonable person" might be read to suggest that a court should take a deferential approach to the probability question. This is the effect of the "reasonable jury" standard currently controlling a judge's summary judgment inquiry. Under the "reasonable jury" standard, a judge is not to independently - and precisely - determine probability from an evidentiary record, but rather is to deferentially determine what range of probability conclusions would be reasonable from the record. See Meier, supra note 12. It seems doubtful that the Tellabs Court intended this type of deferential approach for the PSLRA, considering that the Seventh Circuit standard-reversed by the Court in Tellabs-clearly employed this approach. See Makor Issues \& Rights, Ltd. v. Tellabs, Inc., 437 F.3d 588, 602 (7th Cir. 2006) (holding that a plaintiff must "allege[ ] facts from which, if true, a reasonable person could infer that the defendant acted with the required intent"). Indeed, the Supreme Court seems to explicitly reject this approach when, after quoting the Seventh Circuit approach, it says: "It does not suffice that a reasonable factfinder plausibly could infer from the complaint's allegations the requisite state of mind. Rather, . . . a court . . . must engage in a comparative evaluation . ..." Tellabs, 551 U.S. at 314 (emphasis added). Later, the Court says that "an inference of scienter must be more than merely plausible or reasonable." Id. This language in Tellabs seems to suggest that the "gatekeeping" type of probability analysis that currently occurs at the summary judgment stage is not what is required under the PSLRA. It is important to note that, in describing the analysis required under the PSLRA, the Court states that "a court" must resolve the issue instead of deferring to what a "reasonable factfinder" could conclude. Id. Under a "reasonable jury" standard, it is possible to argue that the jury's role as factfinder is still preserved because the judge is only taking a "quick look" at the evidence to see if a jury determination one way or another would be completely irrational. But see Meier, supra note 12, at 805 (concluding that, although a "reasonable" standard required the judge to be more deferential to the ultimate jury resolution, the judge's analysis is nevertheless still a probability analysis that replicates what is ultimately expected of the jury-if the case makes it that far); Ellen E. Sward, The Seventh Amendment and the Alchemy of Fact and Law, 33 Seton Hall L. Rev. 573, 575 (2003) ("[W]hat is 'reasonable' is often in the eyes of the beholder, meaning that the [reasonable jury] test gives judges more power."). The Court in Tellabs seems to have rejected this sort of approach, however, and, if so, there can be no doubt that a judge's role under the PSLRA is not to act as a sort of gatekeeper but instead to independently decide the probability question. See Meier, supra note 12, at $773 \mathrm{n} .79$ (describing this approach in mathematical terms, namely, as a "point estimate"). It might be tempting to reason that if Congress wanted to employ a deferential "reasonable person" or "reasonable jury" approach in the PSLRA, it could easily have included this language in this statute. This only gets one so far, however, once one realizes that Rule 56, governing summary judgment, does not include this "reasonable jury" language, despite the inclusion of this exact language in Rule 50 for judgments as a matter of law. Compare FED. R. Civ. P. 56, with FED. R. Civ. P. 50.

Despite this (for lack of a better word) mess, the best conclusion appears to be that the Court in Tellabs intended to reverse the "reasonable person" approach of the Seventh Circuit in favor of an approach that requires the trial court judge to come to a specific conclusion regarding the probability of the defendant's scienter. This is the conclusion that Professor Miller appears to reach and it appears to be the conclusion of lower courts that have had to interpret the Tellabs decision. See Miller, supra, at 96-97 \& n.18 (discussing the issue and citing lower court decisions). 
the judge under the PSLRA mirrors the usual burden of persuasion that guides the jury's probability analysis at trial, with the exception that "ties" go to the plaintiff rather than the defendant under the PSLRA. ${ }^{118}$

Upon first impression, the PSLRA's requirement that a judge perform a probability analysis at the pleadings stage might seem ludicrous ${ }^{119}$ : How can anyone make a probability determination regarding disputed factual questions based only on the written pleadings? The written pleadings tell a story, and whether that story is true depends on the evidence that a party can assemble in support of that story. And, evaluating evidence requires the observation of witnesses, in open court, under oath, while facing the heat of cross examination. Under this line of thought, the PSLRA's probability analysis at the pleadings stage seems misguided and contrary to the fundamental distinction between written assertions and evidence.

Upon close inspection, however, there is a logical rationale to the PSLRA's pleading approach. Here, the distinction between circumstantial evidence and direct evidence is instructive. Note that the probability analysis within the PSLRA goes to the issue of the defendant's state of mind. ${ }^{120}$ A defendant's state of mind is a factual question that, in almost all instances, will have to be proven by circumstantial evidence. Moreover, in many instances, the parties will agree on the existence of the circumstantial evidence, but will simply disagree as to the inferences that should be drawn from it.

In this situation, it is entirely feasible to engage in a probability analysis-on the issue of scienter-based solely on the pleadings. The critical

I will, however, take objection to one comment by Professor Miller regarding the "reasonable person" approach. Professor Miller concludes that a "reasonable person" approach is less favorable to a plaintiff because "it is possible that a court, applying its own judgment, would conclude that the facts alleged do support a strong inference of scienter, while still accepting that a reasonable person could conclude that the facts do not support a strong inference of scienter." Miller, supra, at 97. Here, I believe that Professor Miller has misapplied the "reasonable person" test. The question is not simply whether a reasonable person could conclude that there is not scienter, but also whether a reasonable person could conclude that there is scienter. In other words, so long as the range of "reasonable" inferences from the evidence crosses over the governing burden of persuasion (usually a preponderance of the evidence in a civil case), the case must go to the jury. Only if all of the reasonable probability conclusions are on one side of the governing standard can a judge enter judgment under a "reasonable person" approach. See generally Meier, supra note 12 . When you consider that a plaintiff can only lose-but cannot win-at the pleadings stage under the PSLRA, the plaintiff clearly benefits from whichever standard is more likely to result in the continuance of the litigation. This is much more likely to occur under the "reasonable person" standard. Even if a judge believes that the inference of scienter is less than $50 \%$ probable from the plaintiff's narrative, the judge must allow the case to proceed under the "reasonable person" standard unless he believes that a probability conclusion above $50 \%$ would be unreasonable.

118. See Geoffey P. Miller, Pleading After Tellabs, 2009 Wis. L. Rev. 507, 533 (2009) (stating that ties go to the plaintiff under the Court's interpretation of the PSLRA in Tellabs).

119. Makor Issues \& Rights, Ltd. v. Tellabs, Inc., 513 F.3d 702, 705 (7th Cir. 2008) (Posner, J.) ("To judges raised on notice pleading, the idea of drawing a 'strong inference' from factual allegations is mysterious.").

120. See 15 U.S.C. $§ 78 u-4(b)(2)(A)(2012)$. 
question is whether one fact should be inferred from the existence of another fact or set of facts: does "Basic Fact A" (or "Basic Facts A, B, C, etc.") infer the likely existence of the "Material Fact M"? In making this determination on the circumstantial evidence, the critical question is about the real world relationship between the basic facts and the material fact. Evaluating this relationship requires real world experience and common sense, but it does not necessarily require an evaluation of anything that might transpire in a courtroom.

Of course, a dispute about the existence of the circumstantial evidence (the basic facts) might require a full-blown trial, with competing witnesses and cross-examination. A dispute about the actual existence of the plaintiff's circumstantial evidence ("Basic Fact A"), then, could not be resolved on the pleadings. But the analysis established under the PSLRA does not anticipate that this type of factual dispute would be resolved at the pleading stage. This is what the Court meant in Tellabs when it said that "courts must, as with any motion to dismiss for failure to plead a claim on which relief can be granted, accept all factual allegations in the complaint as true." 121 Of course, this statement sweeps too broadly. The issue of the defendant's scienter in a securities fraud case is a factual question, and the plaintiff will have alleged that the defendant had the illegal scienter. Accepting this factual allegation as true renders moot the entire probability analysis established under the PSLRA. What the Tellabs Court obviously meant by this statement is that the existence of the plaintiff's circumstantial evidence on the scienter question must be accepted as true. Once the plaintiff's circumstantial evidence is accepted as true, the remaining step is to determine whether the story told by the plaintiff's circumstantial evidence creates the likely inference that the defendant acted with an illegal state of mind. This probability analysis can be done solely on the pleadings.

Judge Posner's decision in the Tellabs litigation, on remand from the Supreme Court, illustrates how it is possible to do this probability analysis solely from the circumstantial evidence (the truth of which is assumed) contained in the plaintiff's complaint. ${ }^{122}$ The brunt of Judge Posner's analysis is as follows:

The critical question, therefore, is how likely it is that the allegedly false statements that we quoted earlier in this opinion were the result of merely careless mistakes at the management level based on false information fed it from below, rather than of an intent to deceive or a reckless indifference to whether the statements were misleading. It is exceedingly unlikely. The 5500 and the 6500 were Tellabs's most important products. The 5500 was described by the company as its "flagship" product and the 6500 was the 5500's heralded successor. They were to Tellabs as Windows XP and Vista are to Microsoft. That no member of the company's senior management who was in-

121. Tellabs, 551 U.S. at 322. 2008).

122. See generally Makor Issues \& Rights, Ltd. v. Tellabs, Inc., 513 F.3d 702 (7th Cir. 
volved in authorizing or making public statements about the demand for the 5500 and 6500 knew that they were false is very hard to credit . . . 123

Judge Posner's analysis of the plaintiff's circumstantial evidence on the defendant's scienter is rational and persuasive. Most importantly, though, it does not seem to be impaired by the absence of post-pleading proceedings in the courts below. ${ }^{124}$

There is some irony to the fact that Judge Posner authored the Seventh Circuit opinion on remand in Tellabs, in which he analyzed probability solely from the facts alleged in the plaintiff's complaint. In Posner's second edition of his critically acclaimed book "Antitrust Law," 125 he advocates for a modernization of the antitrust trial in a way that roughly mirrors the PSLRA's approach to scienter. Under Posner's proposal, "each party would prepare a chronological narrative of the facts material to his case" 126 and "[t] he parties would then sit down together and, to the extent possible, hammer out an agreed-upon narrative of the relevant facts." 127 This narrative would then "be presented to the trier of fact in a writing that would constitute the basic trial record." 128 If the parties agreed upon the existence of these basic facts, but simply disagreed over the inferences that should be drawn from them, Judge Posner's approach would completely eliminate the need for a traditional trial. ${ }^{129}$ The jury would be presented with the narrative and asked to make inferences therefrom. ${ }^{130}$

Judge Posner's antitrust proposal is the same as the approach of the PSLRA in that both recognize that a traditional trial is unnecessary when the disputed question concerns the inferences to be made from agreedupon facts. Of course, Judge Posner recognized that the parties will not always agree on the basic facts or "narrative" of the case, and in those instances Posner conceded that a full-blown trial will be necessary. ${ }^{131}$ Under the PSLRA, this issue is avoided at the pleadings stage by assuming the existence of the basic facts as pled by the plaintiff. ${ }^{132}$ In this sense, then, at least at the pleadings stage of a securities fraud case, there will be

123. Id. at 709 .

124. In addition, if a plaintiff knows (as, for instance, in the case of the PSLRA) that her circumstantial evidence will be subjected to a judicial probability analysis at the pleadings stage, she can include in the complaint all of the circumstances justifying the plaintiff's conclusion regarding the existence of the material fact, thus assisting the judge's probability inquiry. Cf. Ronald J. Allen \& Alan E. Guy, Conley as a Special Case of Twombly and Iqbal: Exploring the Intersection of Evidence and Procedure and the Nature of Rules, 115 PenN St. L. Rev. 1, 30 (2010) (stating that plaintiffs can react to a pleadings probability requirement "by producing more "evidence' in their pleadings").

125. See generally Richard Posner, Antitrust Law (2d ed. 2001).

126. Id. at 283 .

127. Id.

128. Id.

129. See id. at 284 (describing how his proposal could eliminate the need for a fullblown trial in some cases).

130. See id.

131. See id. at 283-84 (describing when a full-blown trial would be necessary).

132. Tellabs, Inc. v. Makor Issues \& Rights Ltd., 551 U.S. 308, 322 (2007). 
no dispute regarding the "narrative of the case" because the truth of the narrative told by the plaintiff will be assumed.

Thus, the knee-jerk reaction by some against a pleadings stage probability analysis must be dismissed. ${ }^{133}$ It is possible, at the pleadings stage, to consider whether an inference is probable from an assumed set of circumstantial evidence.

Resolving that it is possible to do the probability analysis required by the PSLRA is quite different, however, from concluding that this analysis is constitutional under the Seventh Amendment. ${ }^{134}$ Here again, comparing the PSLRA to Judge Posner's antitrust proposal is useful, but now an important distinction between the two should be drawn. Under Judge Posner's proposal, a full-blown trial is unnecessary, but the jury is preserved as the entity that decides the inferences from the circumstantial evidence. ${ }^{135}$ Under the PSLRA, a probability analysis is also done without a trial but it is the judge, rather than the jury, that performs this analysis. ${ }^{136}$

In Tellabs, the Supreme Court summarily concluded that the probability analysis required under the PSLRA does not intrude upon the right to a jury trial guaranteed by the Seventh Amendment. ${ }^{137}$ The Court's analysis in support of this conclusion, however, is wholly unpersuasive.

The Tellabs Court appeared to make three separate arguments in favor of the constitutionality of the PSLRA procedure. First, the Court stated that "Congress, as creator of federal statutory claims, has power to prescribe what must be pleaded to state the claim, just as it has power to determine what must be proved to prevail on the merits." 138 Under this view, apparently, because Congress has the power to create the cause of action, it has complete authority to define the procedures to be used in adjudicating this action, including having a judge make a determination of probability at the pleadings stage. Stated differently: "Plaintiffs, quit complaining! You are lucky you have this cause of action in the first place, and remember that Congress could always take it away from you!" This argument, of course, would severely undermine the Seventh Amendment. ${ }^{139}$ Could Congress decide that all statutorily created causes of ac-

133. See authorities cited supra note 8 .

134. See U.S. Const. amend. VII ("In Suits at common law, where the value in controversy shall exceed twenty dollars, the right of trial by jury shall be preserved, and no fact tried by a jury shall be otherwise re-examined in any Court of the United States, than according to the rules of the common law.").

135. See Posner, supra note 125, at 283-84.

136. See Tellabs, 551 U.S. at 314.

137. Id. at $326-30$.

138. Id. at 327.

139. Although the Court frames its argument in terms of the authority Congress has to create the cause of action in the first place, there is seemingly no reason that this same rationale would not apply to all causes of actions in our post-Erie world in which law derives from political authority. Does the Court anticipate that the Seventh Amendment would apply differently to a state statutory claim adjudicated in federal court? To a torts or contracts claim under the common law in federal court? The Court has seemingly con- 
tion be tried wholly to a judge based only on the pleadings? Of course not, ${ }^{140}$ but the Court's argument would seem to sanction this result. After all, Congress created the cause of action in the first place, right? The reality is that once Congress has created a cause of action, and the adjudication of that cause of action requires a determination on disputed questions of fact, the Seventh Amendment preserves the jury as the entity that will resolve those disputed questions of fact. ${ }^{141}$ As eloquently stated by Professors Michael Kaufman and John Wunderlich, "Congress cannot use the subterfuge of pleading to allow a judge to make factual determinations that would otherwise be constitutionally required to be resolved by a jury." 142

The Court's second argument in Tellabs in favor of the constitutionality of the PSLRA was based on precedent: "No decision of this Court . . . suggests . . . that the Seventh Amendment inhibits Congress from establishing whatever pleading requirements it finds appropriate for federal statutory claims." 143 To support this assertion, the Court first noted that it had previously sanctioned the heightened pleading requirements of Rule 9(b). ${ }^{144}$ While this is true, the PSLRA is different than Rule 9(b) in a manner that is pertinent to the constitutional issue. The PSLRA requires a judge not just to determine whether certain facts have been pleaded with particularity, but also to determine whether the judge believes those facts infer the likely existence of an additional fact. ${ }^{145}$ In this sense, it is misleading to characterize the approach under the PSLRA as turning on "what must be pleaded to state the claim." 146 A plaintiff who loses under the PSLRA does not lose because what he has written in his complaint is itself inadequate, but rather because the judge believes that a certain inference is not likely from what has been written. The Court's description of the PSLRA approach as depending simply on what must be pleaded, then, is somewhat disingenuous. ${ }^{147}$ The heightened pleading requirement

flated the uncontroversial notion that Congress has power to amend the procedure rules governing federal courts with the incorrect view that Congress has power to amend the procedural requirements of the Seventh Amendment. Congress (acting through the Supreme Court Rules Committee) can establish a uniform set of procedural rules to be used by the federal courts, and Congress can deviate from that approach when it sees fit. But Congress cannot deviate from the procedural requirements of the Seventh Amendment. See, e.g., Feltner v. Columbia Pictures Television, Inc., 523 U.S. 340, 355 (1998).

140. See Curtis v. Loether, 415 U.S. 189, 194 (1974) ("Whatever doubt may have existed should now be dispelled. The Seventh Amendment does apply to actions enforcing statutory rights, and requires a jury trial upon demand, if the statute creates legal rights and remedies, enforceable in an action for damages in the ordinary courts of law.").

141. See Atl. \& Gulf Stevedores, Inc. v. Ellerman Lines Ltd., 369 U.S. 355, 360 (1962).

142. Michael J. Kaufman \& John M. Wunderlich, The Judicial Access Barriers to Remedies for Securities Fraud, 75 Law \& Contemp. Probs. 55, 72 (2012).

143. Tellabs, 551 U.S. at 327.

144. See id.

145. See supra notes 51-59 and accompanying text.

146. Tellabs, 551 U.S. at 327.

147. The Court's description of the PSLRA standard as merely a pleading standard is somewhat analogous to a jury explaining its verdict as a by-product of the Federal Rules of Evidence. For instance, a juror might explain his conclusion by stating that that one party "failed to enter evidence showing the probability of that party's assertion." In reality, how- 
of both Rule 9(b) and the PSLRA requires an examination of the four corners of the plaintiff's complaint, but the PSLRA goes one step further, and therein lays the potential constitutional problem under the Seventh Amendment. The Tellabs Court's comparison of the PSLRA to Rule 9(b) completely misses the constitutional problem, which is not that a plaintiff might have to draft his complaint with a heightened factual specificity, but that a judge is determining probability.

The Court also cites to its previous decision in Fidelity \& Deposit Co. of Maryland v. United States ${ }^{148}$ as undermining the constitutional attack on the PSLRA. ${ }^{149}$ This argument is, like the misplaced reliance on Rule 9(b), off target. I have discussed the Fidelity decision at length elsewhere ${ }^{150}$ and will thus simply repeat the primary conclusions from that examination: The Fidelity case involved a pre-trial judgment against a party pursuant to a confidence, rather than a probability, analysis. ${ }^{151}$ The problem in Fidelity was not that the Court disbelieved the losing party's position and evidence, as might occur under a PSLRA analysis. ${ }^{152}$ Rather, in Fidelity, the Court simply concluded-as a matter of law and policy - that the losing party had not produced the necessary amount of evidence to support his position. ${ }^{153}$ Thus, the Fidelity case is irrelevant when considering the probability analysis required under the PSLRA. ${ }^{154}$

The Tellabs Court's final argument in favor of the constitutionality of the PSLRA was the most bizarre of the three. The Court concluded its discussion of the Seventh Amendment by emphasizing that "a plaintiff is not forced to plead more than she would be required to prove at trial." 155 The Court can make this assertion, of course, only because the Courtrather curiously-resolved that the probability standard under the PSLRA falls just short of the usual burden of persuasion at trial. ${ }^{156}$ Under the PSLRA standard, a plaintiff advances if the trial court judge believes her evidence to be fifty percent probable, ${ }^{157}$ while at trial the plaintiff loses unless the jury is convinced that her version of the facts is

ever, the juror simply did not believe the evidence introduced by that party, and couching his conclusion in terms of the failure to admit certain evidence is simply a roundabout way of expressing that conclusion.

148. See generally Fidelity \& Deposit Co. v. United States, 187 U.S. 315 (1902).

149. See Tellabs, 551 U.S. at 327 (citing Fidelity, 187 U.S. at 320).

150. See generally Meier, supra note 11.

151. See id. at 54-55.

152. See id.

153. See id.

154. The Fidelity case is, however, directly on point when considering the constitutionality of Twombly's plausibility standard. The Twombly standard requires a court to engage in a confidence analysis. As the Fidelity holding makes clear, a confidence analysis does not implicate the Seventh Amendment in the same way that a probability analysis does. These issues are explored more fully in Section III.C.

155. Tellabs, Inc. v. Makor Issues \& Rights, Ltd., 551 U.S. 308, 328 (2007).

156. See id. at 328-29.

157. See id. at 328. 
more probable than the defendant's. ${ }^{158}$ In other words, ties go to the plaintiff at the pleadings stage (under the PSLRA approach) but to the defendant at trial. ${ }^{159}$

The concurring opinions of Justices Scalia and Alito, respectively, would each have applied the usual preponderance standard, under which ties go to the defendant. ${ }^{160}$ Justice Scalia's concurrence, in particular, is sharply critical of the majority's conclusion, and makes several persuasive arguments that undermine whether the Court's "ties go the plaintiff" approach can be justified as a fair interpretation of the PSLRA. ${ }^{161}$ Considering the doubt raised by Justice Scalia as to whether Congress truly intended a "ties go the plaintiff" PSLRA standard, it seems likely that the Tellabs Court attached considerable Seventh Amendment significance to being able to say that "a plaintiff is not forced to plead more than she would be required to prove at trial." 162

Here again, though, the Court has misunderstood the fundamental Seventh Amendment concern. ${ }^{163}$ The problem is that a judge is doing a probability analysis that might resolve the case. This concern is not obviated by the fact that this probability analysis can only work in one party's favor and that the standard by which this probability will be measured is less than the standard that party would have to meet at trial.

To demonstrate, consider a hypothetical new procedure by which a plaintiff, before proceeding to trial, must first independently convince three separate judges that the plaintiff's factual assertions are, more likely than not, true. The first leg of the gauntlet is before the least senior judge, and this judge has two options: either enter judgment against the plaintiff (if the judge believes the plaintiff's facts are not more likely than not) or allow the case to proceed to a second judge. If the case makes it to the second judge, she has the same options as did the first judge but is in no way bound by the prior decision. Supposing that the plaintiff survives the second leg of this gauntlet, the litigation proceeds to the third judge. The third judge has a similar decision: Enter judgment against the plaintiff or allow the plaintiff to proceed to a jury trial.

I hope that every reader concludes that this rather extreme example would constitute a violation of the plaintiff's right to a jury trial. The plaintiff, in essence, must independently convince four separate fact-find-

158. See id. at 328-29; see also Louis Kaplow, Burden of Proof, 121 YALE L.J. 738, 808 (2012) ("In practice, individuals' beliefs are associated with requisite probabilities that depend on the circumstances.").

159. See Miller, supra note 117, at 533 (stating that ties to go the plaintiff under the Court's interpretation of the PSLRA in Tellabs).

160. See Tellabs, 551 U.S. at 329-33 (Scalia, J., concurring); Tellabs, 551 U.S. at 333-34 (Alito, J., concurring) (articulating a standard under which ties go to the defendant rather than the plaintiff).

161. See Tellabs, 551 U.S. at 329-33 (Scalia, J., concurring) (criticizing the majority's conclusion in terms of Congress's likely intent upon passing the PSLRA).

162. Id. at 328 (majority opinion).

163. See id. at 326-27. 
ers before winning a recovery. ${ }^{164}$ A plaintiff cannot win this litigation unless, after surviving the three-judge gauntlet, the jury believes that his evidence makes his version of the facts more likely than not. However, a plaintiff might lose his case, on the facts, before ever reaching a jury. By allowing the three judges to independently determine probability and enter judgment against the plaintiff, the plaintiff's constitutional right to a jury trial under the Seventh Amendment has been infringed.

Does this conclusion change by lowering the probability standard that each of the three judges applies? For instance, suppose in our hypothetical that each of our judges was only to ask whether the plaintiff's version of the facts was $30 \%$ likely? Obviously, the plaintiff would prefer this version of our hypothetical to that in which each judge was applying the preponderance of the evidence standard. But, from a constitutional standpoint, it is difficult to discern why the second version of our hypothetical is any less a violation of the Seventh Amendment than is the first version. Under either standard, a plaintiff might lose a case, on the facts, before ever reaching the jury. According to the Court's reasoning in Tellabs, however, the less demanding probability standard in the second variation of our hypothetical is important to the Seventh Amendment analysis. This reasoning simply fails to appreciate the underlying constitutional concern, which derives not from the burden of persuasion governing a judge's probability analysis, but rather from the fact that the trial court judge is engaging in a probability analysis in a manner that can end the litigation.

Ultimately, my aim in this article is not to resolve the constitutionality of the pleading regime of the PSLRA. Rather, the PSLRA is being used in this Article simply as a means to an end-the correct interpretation of Twombly's plausibility standard. Whereas the PSLRA undoubtedly establishes a probability analysis at the pleadings stage, the analysis required by Twombly's plausibility standard is less clear. In the next section, I argue that Twombly's plausibility analysis requires a confidence analysis rather than a probability analysis. This argument will depend, in part, on the conclusions reached in this section regarding the PSLRA. As this section demonstrates, the probability analysis required by the PSLRA raises-at the very least - serious constitutional concerns under the Seventh Amendment. The constitutional concerns that arise under the PSLRA, however, can be completely avoided if Twombly is interpreted to require a confidence, rather than probability, analysis.

\section{CONFIDENCE AT THE PLEADINGS STAGE: TWOMBLY'S PLAUSIBILITY STANDARD}

The Twombly litigation involved a class action suit on behalf of subscribers of local telephone and internet services against major telecom-

164. To use Professor Kaplow's terminology, this is an extreme example of a type of "multistage adjudication." See Kaplow, supra note 43, at 1186 (using the term). 
munications providers. ${ }^{165}$ The suit alleged violations of Section 1 of the Sherman Act, which prohibits "every contract, combination in the form of trust or otherwise, or conspiracy, in restraint of trade or commerce."166 The plaintiffs in Twombly did not have any direct evidence that the defendants had entered into an illegal antitrust agreement; this is evidenced by the fact that the plaintiffs were not able to describe this purported real world event with any factual specificity. ${ }^{167}$ Instead, the plaintiffs pleaded "upon information and belief" that this agreement had occurred based on the parallel business conduct of the defendants, an event that the plaintiffs were able to describe in meticulous detail. ${ }^{168}$ Although independent parallel conduct is not itself illegal under antitrust law, previous cases had established that the existence of parallel conduct was probative evidence as to whether an illegal conspiracy or agreement had actually taken place. ${ }^{169}$

The district court dismissed the complaint in Twombly, ${ }^{170}$ and this decision was eventually affirmed by the Supreme Court. ${ }^{171}$ In justifying this result, the Court introduced the plausibility test. ${ }^{172}$ This much is clear about the plausibility test in Twombly: the critical inquiry concerns the relationship between the circumstantial evidence described in the pleadings and the ultimate fact that the plaintiff must prove in order to recover from the defendant. In Twombly, this meant that the plausibility analysis considered the relationship between the circumstantial evidence of parallel conduct and the purported agreement alleged by the plaintiffs. What is not clear from Twombly, however, is whether the plausibility analysis requires that this relationship between circumstantial evidence and ultimate fact be viewed from the perspective of probability or confidence. In other words, was the problem in Twombly that the Court doubted the ultimate existence of the conspiracy alleged by the plaintiffs? If so, Twombly's plausibility test is-like the PSLRA standard-a probability analysis. Or, rather, was the problem in Twombly that the Court did not think that parallel business conduct was a sufficient amount of information from which to infer an agreement? In other words, did the Twombly Court believe that, although parallel conduct was an admissible brick, it did not constitute a sufficient wall sufficient to satisfy the plaintiff's burden of production? Most commentators have presumed that Twombly requires-like the PSLRA - a probability analysis. ${ }^{173}$ This view, however, is incorrect.

165. Bell Atl. Corp. v. Twombly, 550 U.S. 544, 550 (2007).

166. Id. (quoting Section 1 of the Sherman Act, 15 U.S.C. $\S 1$ ).

167. See id. at 552.

168. See id. at 550-51.

169. See id. at 556.

170. See Twombly v. Bell Atl. Corp., 425 F.3d 99, 101-02 (2d Cir. 2005).

171. Twombly, 550 U.S. at 548.

172. See id. at 556.

173. See supra notes $3 \& 8$. 
A. Either a Probability Analysis or a Confidence Analysis Can be Performed at the Pleadings Stage

First, it is important to establish that there is no practical impediment to a judge performing either a probability analysis or a confidence analysis at the pleadings stage; both analyses can be done without the development of an evidentiary record or a full-blown trial. Thus, the familiar argument that the plausibility standard compels a judge to perform an analysis that cannot be done at the pleadings stage is simply wrong. ${ }^{174}$

The previous section discussing the PSLRA demonstrated how a probability analysis can occur at the pleadings stage. ${ }^{175}$ The PSLRA requires a judge to consider the probability of the defendant's scienter based on the circumstantial evidence pled-and assumed true-in the plaintiff's complaint. ${ }^{176}$ This inquiry will necessarily be guided by the judge's experience and common sense. Inferring material facts from basic facts does not require a determination regarding the credibility of conflicting witnesses, and thus, there is no need to conduct a full-blown trial in this instance.

If Twombly requires a probability analysis, the inquiry would-similar to the PSLRA - require a determination as to the inferences to be made from circumstantial evidence, which can easily be determined at the pleadings stage. Recall that Twombly's plausibility standard is only triggered when a plaintiff has failed to describe a real world event with a sufficient amount of factual specificity and has instead pleaded the circumstantial evidence that constitutes the basis for the plaintiff's belief that the fact exists. ${ }^{177}$ If Twombly requires a probability analysis, it is only regarding the probability of the material fact from the circumstantial evidence asserted by the plaintiff in the complaint. ${ }^{178}$ Like the PSLRA probability requirement, and as Judge Posner recognized with regard to his proposal for the simplification of antitrust trials, this process of determining probability from circumstantial evidence can be done based on the written narrative contained in the plaintiff's complaint. ${ }^{179}$ Of course, asking a trial court judge to engage in a probability analysis when each party has conflicting, direct evidence regarding the material fact in question would be absurd at the pleadings stage; interpreting Twombly according to a probability analysis does not require this ridiculous act. Plausibility can only be triggered when a party has failed to describe a material fact with factual specificity in the complaint, and this occurs only when a plaintiff is relying solely on circumstantial evidence of a material fact. 180

174. See supra note 9.

175. See supra Part II.

176. See supra notes $109-10$ and accompanying text.

177. See Bell Atl. Corp. v. Twombly, 550 U.S. 544, 553-54 (2007).

178. See id.

179. See Posner, supra note 125 , at 284.

180. See Twombly, 550 U.S. at 585. 
To demonstrate that it is possible to perform a confidence analysis at the pleadings stage of litigation, it is first necessary to understand how a pleadings confidence analysis could work. Recall that a confidence analysis involves a determination about the quantity of evidence on a disputed point rather than the probability estimate that can be drawn from that evidence. ${ }^{181}$ Thus, in the Royals hypothetical discussed earlier in this Article, George decided not to wager that the Royals would win their upcoming game, even though the available evidence suggested that they probably would, because George was not satisfied that he had a sufficient amount of information from which to decide. Similarly, Professor Tribe's blue bus hypothetical required that summary judgment be entered against the plaintiff, even though the summary judgment record suggested that the defendant probably owned the bus that had injured the plaintiff, because there was not a sufficient amount of information to justify sending the case to the jury.

A confidence analysis, at the pleadings stage, would analyze whether the circumstantial evidence pleaded in the plaintiff's complaint constituted a sufficient amount of evidence regarding the material fact to the litigation that the plaintiff ultimately needed to prove. ${ }^{182}$ This question as to whether the plaintiff had "enough" evidence could be analyzed two different ways.

First, a court could ask whether the circumstantial evidence described in the plaintiff's complaint would constitute a sufficient amount of evidence such that the plaintiff could survive the court's confidence analysis at the summary judgment stage. ${ }^{183}$ At the summary judgment stage, a confidence analysis asks whether there is a sufficient amount of information such that we can have a requisite level of confidence in any determination made by the jury. ${ }^{184}$ A confidence analysis, at the pleadings stage, could simply move this inquiry up in the litigation. ${ }^{185}$ Under this view, then, a court employing a confidence analysis at the pleadings stage would ask whether the circumstantial evidence pleaded in the complaint would be a sufficient quantity of evidence to permit the plaintiff to proceed past summary judgment to a jury determination. ${ }^{186}$

Of course, this view of a pleadings confidence analysis undermines the significance of discovery. Under this version of the pleadings confidence analysis, the plaintiff would be required to have a sufficient amount of evidence - at the outset of the case-to satisfy the plaintiff's confidence

181. See Meier, supra note 12 , at $778-94$.

182. Recall (1) that a complaint drafted with sufficient factual specificity will not be subject to a plausibility analysis, (2) that a plaintiff with direct evidence of a material fact will be able to satisfy the factual specificity requirement because he will be able to describe the material fact with factual detail, and (3) that a plausibility analysis will thus only be triggered when a plaintiff has (at the outset of the case) only circumstantial evidence regarding a material fact to the litigation. See generally Meier, supra note 12, at 753-56.

183. See id. at $750-51$.

184. See id.

185. See id. at 754-58.

186. See id. 
burden at summary judgment. ${ }^{187}$ Another view of a pleadings confidence inquiry, however, would apply a more lenient confidence analysis to the plaintiff at the pleadings stage than at the summary judgment stage. Under this view, the judge would not ask whether the plaintiff's evidence would satisfy the confidence burden at summary judgment, but instead would ask whether the plaintiff has a sufficient amount of evidence at the outset of the litigation so as to allow the litigation to proceed to discovery. This type of confidence analysis could turn, for example, on the cost of allowing the case to proceed to discovery or the likelihood that discovery would lead to the type of evidence that would satisfy the plaintiff's summary judgment confidence burden. ${ }^{188}$

Later in this Article, I will briefly return to a discussion of how a confidence analysis might function at the pleadings stage. For now, though, it is important to note that a confidence analysis-like a probability analysis-can be performed at the pleadings stage; a judge does not need live testimony or cross examination, in open court, to determine whether the plaintiff has pleaded a sufficient amount of circumstantial evidence to satisfy any confidence burden that might apply at the pleadings stage.

Thus, the familiar objection to Twombly's plausibility requirement as beyond the capacity of a judge at the pleadings stage of litigation is simply misplaced. Either way, the judge has to analyze the relationship between the circumstantial evidence alleged by the plaintiff (which is assumed true) and the material fact to the litigation, and a judge can analyze this relationship from the perspective of either probability or confidence without the need for actual evidence or testimony.

\section{B. The Supreme Court's Use of the Word "Plausible"}

In attempting to determine the type of analysis required under Twombly's plausibility standard, the natural place to start is the Twombly opinion. ${ }^{189}$ Unfortunately, the manner in which the Court described "plausibility" in Twombly does little to resolve whether a probability or confidence analysis is required under the plausibility analysis. ${ }^{190}$

In introducing the plausibility standard, the Court strongly disavows the notion that the standard requires a probability analysis: "[a]sking for plausible grounds to infer an agreement does not impose a probability requirement at the pleading stage." 191 Moreover, the Court proceeds to comment that the plausibility inquiry involves a determination as to whether "enough fact[s]" have been pleaded. ${ }^{192}$ An analysis involving the

187. See id.

188. See id. at 805-10 (discussing the policy concerns informing a confidence analysis).

189. See generally Bell Atl. Corp. v. Twombly, 550 U.S. 544 (2007).

190. See id. at 555-56.

191. Id. at 556 ("And, of course, a well-pleaded complaint may proceed even if it strikes a savvy judge that actual proof of those facts is improbable and 'that a recovery is very remote and unlikely." ").

192. Id. at 556; see also id. at 570 (stating that a complaint must contain "enough facts to state a claim to relief that is plausible on its fact") (emphasis added). 
quanta of facts is a confidence analysis. In the Royals example, George decided not to place a wager because he felt that he did not have the necessary amount of information from which to decide.

Other portions of the Twombly opinion, however, suggest that the plausibility analysis does require a probability analysis, despite the Court's pronouncement to the contrary. ${ }^{193}$ For instance, the Court states that the dispositive inquiry is whether the complaint crosses "the line between possibility and plausibility." 194 This phrase suggests that "possibility" and "plausibility" are measuring the same quality—probability—with plausibility simply being a more demanding measure. ${ }^{195}$ For instance, Professor Bahadur reasons that equating "possibility" with "plausibility" must mean that Twombly's plausibility standard involves a probability analysis:

The Court's use of the term "possibility," however, belies the assertion that plausibility is not a probability analysis because possibility is an expression of probability. ... [T] The Court's necessary mathematical conclusion is that the probability of [the dispositive fact] is greater than $0 \%$ but not probabilistically high enough to be plausible. Plausibility is therefore achieved when the complaint reaches a threshold level of probability . . . ${ }^{196}$

Other language in the Twombly opinion describing the plausibility analysis also creates the impression that it requires probability rather than confidence. ${ }^{197}$

The schizophrenic nature of the Court's description of the plausibility analysis mirrors how the term "plausibility" is used in non-legal settings. The term "plausible," as it is commonly defined, can mean either probability or confidence-or both.

In some instances, the word "probability" or "confidence" will appear within the definition of "plausible." Consider the following definition: "seeming reasonable or probable." 198 Pointing in the other direction is the following definition of plausibility: "well-spoken and apparently, but

193. See id. at 557.

194. Id.; see also id. at 570 (stressing the need for a plaintiff to cross the "line from conceivable to plausible").

195. See id. at 557.

196. Bahadur, supra note 8 , at 456-57.

197. See Twombly, 550 U.S. at 549 (stating that a complaint should be dismissed when there is no "factual context suggesting [an] agreement"); id. at 556 (describing the relevant inquiry as "identifying facts that are suggestive enough to render a $\$ 1$ conspiracy plausible"); id. at 557 (declaring that "parallel conduct does not suggest conspiracy"; that allegations of parallel conduct "must be placed in a context that raises a suggestion of a preceding agreement"; and that "for allegations plausibly suggesting (not merely consistent with) agreement"); $i d$. at $557 \&$ n.5 (describing Twombly as a case involving the line "between the factually neutral and the factually suggestive"). The term "suggest" is consistent with a probability analysis. See Suggest definition, Merriam-Webster Online DictionARY, http://www.merriam-webster.com/dictionary/suggest (last visited May 18, 2015) (defining "suggest" as "to mention or imply as a possibility").

198. See Plausible Definition, Oxford Dictionary (2002) (emphasis added). 
often deceptively, worthy of confidence or trust."199 Other definitions do not employ the term probability or confidence but nevertheless seem to incorporate both the probability concept and the confidence concept within the same definition. For instance, Random House Webster's College Dictionary defines plausible as: "having an appearance of truth or reason; credible; believable." 200 The "appearing true" portion of this definition is consistent with a probability analysis, as a probability analysis is concerned only with the likelihood of particular facts. On the other hand, the "appearing . . . believable" definition is much more consistent with a confidence definition; whether someone chooses to "believe" in the existence of a particular fact requires an assessment of what is at stake. ${ }^{201}$ Recall the hypothetical involving George, who was trying to make a decision as to whether to place a wager on an upcoming Royals game with a friend. George decided not to "believe" that that the Royals would win their next game, even though the limited information available suggested that there was a $60 \%$ chance they would, because George either wanted additional information regarding the upcoming game or because George was risk averse. ${ }^{202}$ Consider also the following definition: "[s]eemingly or apparently valid, likely, or acceptable." 203 Here again, the "likely" component suggests a probability analysis. Whether something is "valid" or "acceptable," however, depends on context: What are the consequences of determining that something is "valid" or "acceptable"? What is the information going to be used for? What are the consequences of an erroneous probability determination? These questions are more akin to a confidence analysis rather than a probability analysis.

In short, the everyday manner in which the term "plausibility" is used in ordinary language does little in resolving whether a probability or confidence analysis is required under Twombly. Indeed, the Supreme Court could not have picked a more ambiguous word with regard to the distinction between probability and confidence.

The Supreme Court's subsequent cases discussing or applying the plausibility standard also do little towards distinguishing between a probability and confidence analysis. The most extensive discussion of the

199. See Plausible Definition, Dictionary.com, http://www.dictionary.reference.com/ browse/plausible?s=t (last visited May 18, 2015) (emphasis added).

200. See Plausible Definition, Random House Webster's College Dictionary 1035 (1992).

201. See Richard W. Wright, Perspectives on Causation 81 (R. Goldberg ed., 2011) ("[A] mere statistical probability, no matter how high, will not suffice in the absence of the required conviction or belief in the truth of the facts at issue."); cf. Kaplow, supra note 158, at 808 ("In practice, individuals' beliefs are associated with requisite probabilities that depend on the circumstances.").

202. See also Plausible Definition, Merriam-Webster's Online Dictionary http:// www.merriam-webster.com/dictionary/plausible (last visited May 18, 2015) (defining plausible as "appearing worthy of belief"); Plausible Definition, OXFORD ENGLISH DictionARY (2005) (defining plausible as follows: "Of an argument or statement seeming reasonable or probable"). 2015).

203. See Wiktionary.COM, http://en.wiktionary.org/wiki/plausible (last visited May 18 , 
plausibility standard occurred in Ashcroft v. Iqbal. ${ }^{204}$ The Iqbal litigation was commenced by several individuals who had been arrested and detained by federal officials after the September 11, 2001, terrorist attacks. ${ }^{205}$ The plaintiffs claimed that John Ashcroft and Robert Mueller had been involved in shaping the government's post-9/11 policy and that their involvement had been fueled by an unconstitutional discriminatory animus. ${ }^{206}$ In support of this allegation of discriminatory intent, and in the absence of direct evidence of this alleged discriminatory intent, the plaintiffs alleged a host of facts which suggested that the policy might have been fueled by racial animus. ${ }^{207}$ As in Twombly, it is clear that the Iqbal Court was using plausibility as a measure of the relationship between the circumstantial evidence of racial discrimination alleged in the complaint and the ultimate fact of the defendants' discriminatory intent. Also like Twombly, however, it is unclear whether the Iqbal Court was considering this relationship from the perspective of probability or confidence. ${ }^{208}$

In describing the plausibility analysis, the Iqbal Court rehabilitated some of the contradictory language from the Twombly opinion. For instance, the Court stated that the "plausibility standard is not akin to a 'probability requirement.' "209 Immediately after disclaiming a probability analysis, however, the Court stated that plausibility required "more than a sheer possibility that a defendant has acted unlawfully." 210 A discussion of the "sheer possibility" that a defendant has acted illegally sounds very much like a probability analysis. ${ }^{211}$

The Court's subsequent citations to Twombly are similarly unhelpful. In addition to Iqbal, the Supreme Court has cited Twombly five times. In terms of delineating between probability and confidence, the Court's opinion in Matrixx Initiatives $v$. Siracusano ${ }^{212}$ is the most noteworthy because the Court applied Twombly's plausibility analysis and the PSLRA probability approach to different elements of the same complaint. The

204. See generally Ashcroft v. Iqbal, 556 U.S. 662 (2009).

205. See Elmaghraby v. Ashcroft, NO. 04-01809 2005 WL 2375202, at *1 (E.D.N.Y. Sept. 27, 2005).

206. Iqbal, 556 U.S. at 668-69.

207. See id. at $681-84$.

208. There is a compelling argument that the Iqbal Court was employing "plausibility" as a term of confidence, particularly considering the rather complicated jurisprudence that has developed regarding the burden of production and the quantity of evidence that must be submitted in a civil rights cases. See generally Henry L. Chambers, Jr., Recapturing Summary Adjudication Principles in Disparate Treatment Cases, 58 SMU L. Rev. 103, 104-06 (2005) (discussing the complex set of rules regarding the burden of production in Title VII discrimination cases). In any event, as I have explained in a previous article, the Iqbal Court misapplied the Twombly decision on the question of when a plausibility analysis is required. The Iqbal Court erred in proceeding to a plausibility analysis, which somewhat undermines the importance of the way in which the Court applied the plausibility test in that case. The Iqbal Court should never have even gotten to this point. See Meier, supra note 5 , at $755-56$.

209. Iqbal, 556 U.S. at 678.

210. See id.

211. See supra notes 192-97 and accompanying text.

212. See generally Matrixx Initiatives, Inc. v. Siracusano, 131 S. Ct. 1309 (2011). 
suit involved a $\S 10(\mathrm{~b})$ securities fraud claim, which required the plaintiffs to prove that the defendant made a material misrepresentation or omission and that the defendant acted with scienter. ${ }^{213}$ In Matrixx, the plaintiffs' complaint had been dismissed on the theory that the materiality and scienter elements were lacking. ${ }^{214}$ In reversing, the Supreme Court applied Twombly's plausibililty standard to the materiality question ${ }^{215}$ and PSLRA's probability requirement to the question of the defendant's scienter. ${ }^{216}$

Constitutional objections aside, the application of the PSLRA standard to the scienter question in Matrixx was straightforward and not noteworthy. The Court's application of plausibility to the materiality question, however, is puzzling because "materiality" is not a question of historical fact like the alleged antitrust agreement in Twombly or the alleged discriminatory intent in Iqbal. Thus, it is somewhat difficult to determine why the Matrixx Court was even applying the plausibility standard.217

213. See id. at 1318.

214. See id. at 1317.

215. See id. at 1322-23.

216. See id. at 1323-24.

217. There is no question that the question of whether a misrepresentation is "material" is a question of law; the concept of "materiality" is a legal concept and not a fact that did-or did not-exist in the real world. Whether a misrepresentation occurred is a question of fact, but distinguishing material misrepresentations from nonmaterial misrepresentations requires a legal analysis. See id.

Within the context of securities, there are a multitude of legal definitions of this concept. See Recent Case, Securities Law-Materiality Requirement-Second Circuit Finds Issuer's Failure to Disclose Loan Impairments Immaterial as a Matter of Law-Hutchison v. Deutsche Bank Securities Inc., 647 F.3d 479 (2d Cir. 2011), 125 Harv. L. Rev. 1282, 1286-88 (2012) (discussing the different definitions of "materiality" in the securities context). The Supreme Court crafted a uniform approach to determining "materiality" for all securities litigation in TSC Industries, Inc. v. Northway, Inc., 426 U.S. 438 (1976). Under the "objective" approach articulated in TSC Industries, the question is whether the misrepresentation might affect the decision of a "reasonable" recipient of that information. See $i d$. at 445 . Thus, with regard to proxy statements to shareholders, the Court has stated that the materiality exists "if there is a substantial likelihood that a reasonable shareholder would consider it important in deciding how to vote." Id. at 449. Similarly, in the context of a company's misrepresentation about a potential merger, the Court has stated that "materiality depends on the significance the reasonable investor would place on the withheld or misrepresented information." Basic Inc. v. Levinson, 485 U.S. 224, 240 (1988). The Court's articulation of the materiality test in Basic is sometimes referred to as to the "total mix" standard. Matrixx, 131 S. Ct. at 1322.

In Matrixx, the Court rejected the bright-line rule, proposed by the defendants, that "reports of adverse events associated with a pharmaceutical company's products cannot be material absent a sufficient number of such reports to establish a statistically significant risk that the product is in fact causing the events." Id. at 1318-19. Instead, the Court said that the materiality question will depend upon the "contextual inquiry" of "Basic's 'total mix' standard." Id. at 1321-22.

Besides rejecting the bright-line rule proposed by the defendants, and adhering to the Basic test for materiality, it is unclear as to what else was resolved in Matrixx. Namely, did the Court determine that the plaintiffs were entitled to proceed past the motion to dismiss case, or did the Court decide - as a matter of law - that the materiality element was satisfied, assuming that the plaintiff could prove the facts alleged in the complaint? The Court's decision says both. Compare id. at 1322 ("[W]e conclude that respondents have adequately pleaded materiality."), and id. at 1323 ("We believe that these allegations suffice to 'raise a reasonable expectation that discovery will reveal evidence' satisfying the materiality requirement." (quoting Twombly)), with id. at 1323 ("Assuming [the facts al- 
leged in the complaint] to be true, these were material facts 'necessary in order to make the statements made, in the light of the circumstances under which they were made, not misleading." (quoting Rule 10b-5(b)). The issue was never resolved in the Matrixx litigation, as the case settled after the Supreme Court's decision. Communications with one of the plaintiffs' attorneys in Matrixx revealed that the plaintiffs viewed the Supreme Court's decision as a complete, final victory on the materiality question; according to the plaintiffs, they had won the materiality issue at the Supreme Court level. Compare this reading of Matrixx to the view that the plaintiffs had simply cleared a preliminary hurdle by winning in the Supreme Court with an ultimate decision to be made after further litigation. I assume that this is how the defendants, on remand in Matrixx, would have characterized the Supreme Court's decision, although my attempts to communicate with the defendants' attorneys, in order to get their perspective on what was resolved in the Matrixx opinion, were unsuccessful.

These ambiguities regarding the Matrixx opinion make it virtually impossible to draw any conclusions from that decision regarding the nature of the plausibility test. More fundamentally, questions regarding the nature of the materiality inquiry itself add to the difficulty because it is not entirely clear whether the dispositive analysis under the materiality question should be determined by the judge or the jury. Previously in this footnote, I made the obvious observation that whether a misrepresentation is "material" involves a legal determination rather than a conclusion on a material fact. This obvious statement, however, does not preclude the possibility that a jury would be asked to resolve this legal question. There are a variety of legal rules, whose application depends on fact-specific context, that are given to the jury to resolve. Thus, the materiality question might be for either the judge or the jury, depending on the legal definition for materiality.

Under the "objective" standard for determining materiality, first articulated in Northway, the question is whether the misrepresentation would matter to the "reasonable" recipient of that information. TSC Indus., Inc. v. Northway, Inc., 426 U.S. 438, 445 (1976). Framing the materiality inquiry in terms of how a "reasonable" person would be affected by the faulty information obviously provokes an analogy to the "reasonable person" test under tort law for determining negligence and suggests that the application of this legal rule should be decided by a jury. Not surprisingly, then, in Northway, the Court drew this precise comparison in describing the materiality question as a "mixed question of law and fact" but also stating that-similar to the negligence issue within tort law-this inquiry is "peculiarly one[] for the trier of fact" unless the correct decision is "obvious[ ]." Id. at 450 $\&$ n.12. Other courts have viewed materiality as a question for the jury. See, e.g., S.E.C. v. Conaway, 698 F. Supp. 2d 771, 821 (E.D. Mich. 2010) (discussing the materiality jury charge for a $\$ 10(\mathrm{~b})$ claim).

The problem with defining the materiality element with primary reference to the reasonable person standard in tort law is that the jury is serving a normative function in the torts context. The jury is not simply to determine what the average person would do, but rather what the average person should do. For instance, a defendant's compliance with industry custom is evidence of reasonableness but is not determinative. See The T.J. Hooper, 53 F.2d 107, 111 (S.D.N.Y. 1931) (Hand, J.) (finding that compliance with industry custom was evidence of the defendant's reasonableness but not conclusive on the matter). Similarly, a defendant's failure to comply with industry custom is evidence of a breach but is not determinative. See Gideon Parchomovksy \& Alex Stein, Torts and Innovation, 107 Mich. L. REv. 285, 291-92 (2008) (stating that a defendant's failure to comply with industry custom is evidence of negligence but that the defendant can introduce contradictory evidence and thus create a jury issue). With regard to materiality, however, the Court does not seem to contemplate that this "objective" analysis will require a normative judgment. Rather, the Court seems to envision a determination about how the average person would react, rather than should react, to the misrepresentation of the defendant.

If the materiality test is a question of how most/many/some investors would react to the defendant's misrepresentation, there is a clearer way to ask that question: did the misrepresentation affect the market price for this security? After all, the market price for a particular security reflects the myriad views of real people regarding value. Under this articulation of the materiality analysis, the focus of the inquiry has changed to a causation inquiry (specifically, a cause-in-fact inquiry) from the previous "reasonableness" inquiry. And, indeed, it seems as if the Court is beginning to make this transition in Matrixx; the Matrixx opinion frequently employs the term "causation" in analyzing the materiality question. See generally Matrixx, 131 S. Ct. 1309. 
The Court's other citations to Twombly are, like the Matrixx decision, unhelpful in determining whether plausibility means probability or confi-

The determination of cause-in-fact is, like the question of "reasonableness," usually submitted to the jury. Of course, the jury's determination of cause in fact is different than the jury's determination of an historical fact; an historical fact requires a jury to determine what did happen, while cause-in-fact requires a jury to determine what would have happened if the defendant had complied with the law. See David W. Robertson, The Common Sense of Cause in Fact, 75 TEx. L. REv. 1765, 1770 (1997) (explaining the counterfactual nature of a cause-in-fact inquiry). Nevertheless, the jury is usually thought to be at an advantage (compared to the judge) in resolving this counterfactual determination, and thus causation is usually submitted to the jury. See Luke Meier, Using Tort Law to Understand the Causation Prong of Standing, 80 Fordham L. Rev. 1241, 1249 (2011) (explaining that cause in fact is usually considered a jury question).

Thus, one can make an argument that Matrixx-like Twombly and Iqbal-employed the plausibility test to a specific question that would ultimately be submitted to the jury. Under this view, the ultimate question the Matrixx Court was resolving was the potential that the defendant's misrepresentations affected the market price of the defendant's stock. The plaintiffs' complaint was analyzed as to whether the circumstantial evidence alleged in the complaint satisfied the "plausibility" requirement such that the plaintiff could proceed in the litigation. Under this reading of Matrixx, the Court resolved this question (unlike in Twombly and Iqbal) in favor of the plaintiff, meaning that the litigation could advance past the 12(b)(6) stage.

Under this interpretation, however, it still is not clear whether the plausibility analysis is being employed as a term of probability and confidence. Did the Court believe that the allegations in the complaint made it probable that the market price was affected by the misinformation, or did the Court simply conclude that the plaintiffs had alleged a sufficient amount of information such that the jury should be allowed to make a probability determination or that, at least, the plaintiff should be allowed to proceed to discovery? The $M a$ trixx opinion does little to resolve this question.

It is not clear, however, that the jury question/plausibility reading of Matrixx is accurate. At the end of the Court's decision in Matrixx, the Court's couches its ultimate conclusion on the "materiality" question in a manner that suggests that the issue has been affirmatively resolved-as a matter of law-in favor of the plaintiff. If this is what was determined in Matrixx, this conclusion seems incompatible with the view that Matrixx involved-like Twombly and Iqbal - an application of the plausibility analysis. In Twombly and Iqbal, the Court applied plausibility to a question that would ultimately be resolved by the jury, finding the plaintiffs' allegations insufficient to allow the cases to proceed. There was no suggestion in either Twombly or Iqbal, however, that a conclusion in favor of plausibility would conclusively resolve-as a matter of law-the factual issue for the plaintiff. Or, at least, this would be a dramatic upheaval in the manner in which the plausibility test has been understood. The common view of plausibility (as applied to a plaintiff's complaint) is that the analysis can end the litigation in a manner that is favorable to the defendant but not in a manner that is favorable to the plaintiff; plausibility, then, is a one-way street. It would be odd for the Court to alter the common perception of plausibility as an analysis that can only help defendants to an analysis that can be employed by either party without more attention to the issue. And, of course, the "plausibility" term itself seems inconsistent with this usage: it makes sense to say that a defendant should win the case if the plaintiff's complaint is not plausible, but it makes little sense to say that a plaintiff should win a case if her complaint is plausible.

Thus, if the Supreme Court in Matrixx resolved the materiality question as a matter of law, in favor of the plaintiff (and remember that this is how the plaintiffs' lawyers viewed the decision), this result would seem to be most consistent with the view that materiality is a question that should be decided by a judge rather than submitted to a jury. Under this view of the Matrixx decision, the Court's analysis is completely irrelevant to attempting to understand the plausibility test because the Court was concerned with a matter that needed to be resolved by the judge rather than the jury.

In conclusion, I do not have any clear answers when it comes to attempting to discern what Matrixx means with regard to Twombly's plausibility analysis. The following, however, seems valid: anyone citing Matrixx as clear support for any conclusion regarding the plausibility analysis has not, in my opinion, appreciated the complexity of the case. 
dence. ${ }^{218}$ A consideration of the Court's other cases that make extensive use of the term "plausibility," however, does offer some clues as to whether the Court intended plausibility to involve a confidence or probability analysis.

The Court has historically employed the term "plausible" or "plausibility" with surprising frequency. ${ }^{219}$ The two opinions (other than Twombly

218. In Pitre v. Cain, Justice Sotomayor cited Twombly in her dissenting opinion from the Court's denial of certiorari. See Pitre v. Cain, 131 S. Ct. 8, 9 (2010) (Sotomayor, J., dissenting from denial of petition for certiorari). Justice Sotomayor cited Twombly for the proposition that "[w]hen a complaint adequately states a claim, it may not be dismissed based on a district court's assessment that the plaintiff will fail to find evidentiary support for his allegations." Id. This statement is somewhat circular because it assumes the very question that Twombly addresses: whether a claim adequately states a claim. Moreover, the fundamental question in Pitre was whether the plaintiff's complaint had "state[d] an Eighth Amendment violation," and thus did not involve the questions of historical fact to which the plausibility analysis was applied in Twombly and Iqbal. Id. at 8. In Pacific Bell Telephone Co. v. Linkline Communications, Inc., the Court cited Twombly only as part of the Court's instructions on remand to the district court to consider whether the plaintiff's complaint had stated a claim under Rule 8. See 555 U.S. 438, 456 (2009). In his Credit Suisse Securities (USA) LLC v. Billing concurrence, Justice Stevens cited his Twombly dissent. See 551 U.S. 264, 287 (2007) (Stevens, J., concurring). Justice Stevens compared the result in Credit Suisse, in which the Court determined-as a matter of law-that securities law precluded an antitrust claim against underwriting firms that market and distribute newly issued securities, with the result in Twombly, which (according to his dissenting opinion) required "discovery to determine whether there is any merit to the plaintiffs' claims." Id. Finally, in the much discussed case of Erickson v. Pardus, 551 U.S. 89 (2007), the Court cited Twombly in reversing the dismissal of a prisoner's pro se complaint. Id. at 93. The Court referenced Twombly as preserving the notice pleading approach of the Federal Rules of Civil Procedure, see id. at 93-94, but also noted that a pro se complaint should be judged differently than a complaint drafted by a lawyer. See id. at 94 . Like many others, I am not sure what to make of Erickson, except to say that the per curiam opinion offers little guidance on the nature of the plausibility analysis. See, e.g., Allen \& Guy, supra note 124, at 2 (describing the Erickson case as a "puzzle"); Robert G. Bone, Twombly, Pleading Rules, and the Regulation of Court Access, 94 Iowa L. Rev. 873, 883 (2009) (stating that Erickson "confuse[d] matters even further").

219. The Court has used the term "plausibility" in 242 opinions, starting with the Court's opinion in Silsby v. Young, 7 U.S. 249, 261 (1806). The term "plausible" shows up in 1106 opinions, the first of which was Penhallow v. Doane's Administrators, 3 U.S. (3 Dall.) 54, 86 (1795). A scan of these cases indicates that the plausibility term is sometimes employed as a term of probability. See, e.g., Bobby v. Dixon, 132 S. Ct. 26, 28 (2011); Christian Legal Soc'y Chapter of the Univ. of Cal., Hastings Coll. v. Martinez, 561 U.S. 661, 737 (2010) (Alito, J., dissenting); Morse v. Frederick, 551 U.S. 393, 402 (2007) (all using "plausibility" to discuss the probability of a party's factual contentions); Doe v. Reed, 561 U.S. 186, 217 (2010) (Stevens, J., concurring); Crawford v. Marion Cnty. Election Bd., 553 U.S. 181, 235 (2008) (Souter, J., dissenting) (both of which employ the term "plausible" to discuss the probability of the proffered factual justifications for a particular statute). In other instances, the term "plausible" is used to describe the likely intent motivating a particular statement, and in this sense is being used as a term of probability. See, e.g., Renico v. Lett, 559 U.S. 766, 778 (2010) (using the term "plausible" to describe the likely intent behind a juror's statement); F.A.A. v. Cooper, 132 S. Ct. 1441, 1448 (2012); Morgan Stanley Capital Grp., Inc. v. Pub. Util. Dist. No. 1 of Snohomish Cnty., 554 U.S. 527, 551 n.6 (2008); United States v. Rodriquez, 553 U.S. 377, 394 (2008) (Souter, J., dissenting) (all using the term "plausible" or "plausibility" to discuss Congress's likely intent behind statute). In other instances, however, the Court uses "plausible" or "plausibility" in a manner that does not denote a probability analysis. See, e.g., Nat'l Fed'n of Indep. Bus. v. Sebelius, 132 S. Ct. 2566, 2656 (2012); Harrington v. Richter, 131 S. Ct. 770, 789 (2011) (both of which use the term "plausibility" to discuss the persuasiveness of a party's legal argument). 
and Iqbal) in which the Court used the term most prevalently (and in a context that is potentially helpful to figuring out what the Twombly Court intended) were Matsushita Electric Industrial Co. v. Zenith Radio Corp. ${ }^{220}$ and Tellabs, Inc. v. Makor Issues \& Rights, Ltd. ${ }^{221}$ In Matsushita, the Court used "plausibility" to indicate a confidence analysis while in Tellabs the Court employed the term as part of a probability analysis. ${ }^{222}$

In Matsushita, the Court affirmed a summary judgment for the defendants in an antitrust case based on the conclusion that the summary judgment record in that case rendered the plaintiffs' allegation of conspiracy "implausible." 223 As I have explained at length elsewhere, the Court's use of "plausibility" in Matsushita represented a confidence, rather than a probability, analysis. ${ }^{224}$ The reason that the plaintiffs lost at summary judgment in Matsushita was not that the Court necessarily doubted the probability of the antitrust conspiracy alleged by the plaintiffs, but rather that there was so little evidence on this question that little confidence could be had in any probability conclusion drawn from the scant record. ${ }^{225}$ In Matsushita, the plaintiffs' evidence regarding the alleged conspiracy consisted primarily of the parallel business activity of the defendants. ${ }^{226}$ The Court concluded-similar to Professor Tribe's blue bus hypothetical discussed earlier in this paper ${ }^{227}$ - that this was simply not a sufficient amount of evidence from which to permit a probability decision to be made by the jury. ${ }^{228}$

The use of "plausibility" as a term of confidence in Matsushita, however, should be contrasted with how that term was employed in Tellabs. The term "plausible" is sprinkled throughout the Tellabs opinion to describe the pleading analysis required under the PSLRA. ${ }^{229}$ And, as discussed previously, there is no question that this analysis is a probability analysis. 230

Thus, at first blush, Matsushita and Tellabs seem to point in different directions regarding Twombly's use of the term "plausibility." On one hand, Matsushita involved almost the exact same antitrust issues as did Twombly, so it stands to reason that the Court's use of "plausibility" in Twombly represented the same analysis as that involved in Matsushita. ${ }^{231}$

220. See generally Matsushita Elec. Indus. Co. v. Zenith Radio Corp., 475 U.S. 574 (1986).

221. See generally Tellabs, Inc. v. Makor Issues \& Rights, Ltd., 551 U.S. 308 (2007).

222. See Meier, supra note 14 and accompanying text; see also supra note 57 and accompanying text.

223. Matsushita, 475 U.S. at 587.

224. See Meier, supra note 14 and accompanying text (explaining why Matsushita should be understood as being resolved according to a confidence analysis).

225. See Matsushita, 475 U.S. at 597.

226. Id. at 579 .

227. See supra text accompanying note 73 .

228. See Matsushita, 475 U.S. at 597.

229. See Tellabs, Inc. v. Makor Issues \& Rights, Ltd., 551 U.S. 308, 313, 317, 323 (2007).

230. See supra note 117.

231. See Bell Atl. Corp. v. Twombly, 550 U.S. 544, 585-86 (2007). 
On the other hand, Tellabs was decided only months after Twombly, ${ }^{232}$ so it is logical that the Court would intend to use the term consistently in these nearly contemporaneous decisions. Moreover, Tellabs, like Twombly, is a pleadings case, while Matsushita is a summary judgment case. ${ }^{233}$ Thus, if one considers the procedure involved, Tellabs, use of the term "plausibility" would suggest the same usage was meant in Twombly.

Upon further consideration, however, there are compelling reasons to believe that the Twombly Court thought it was using the Matsushita version of "plausibility" (confidence) rather than the Tellabs version (probability). The Matsushita decision is cited by the Twombly Court as authority for the plausibility standard. ${ }^{234}$ Granted, the Court could not have cited the Tellabs decision in Twombly because the Tellabs opinion had not been issued when Twombly was handed down. ${ }^{235}$ That said, the Twombly decision was not cited within the Tellabs opinion. ${ }^{236}$ This is significant when one considers the issue that the Court was wrestling with in Tellabs. In Tellabs, the Court was interpreting the pleading requirements of the PSLRA.237 As discussed above, the Court assumed that the PSLRA imposed a probability requirement at the pleadings stage; the question in Tellabs was the measure of probability that a judge would apply at the pleadings stage. ${ }^{238}$ If Twombly truly imposed a probability requirement at the pleadings stage, it is difficult to discern why the Court would not reference this standard as a benchmark in trying to fix the standard required under the PSLRA. ${ }^{239}$ Numerous commentators have

232. See Tellabs, 551 U.S. at 308 (indicating that Tellabs was decided on June 21, 2007); Twombly, 550 U.S. at 544 (indicating that Twombly was decided on May 21, 2007).

233. See Tellabs, 551 U.S. at 313-14; Twombly, 550 U.S. at 548-49; Matsushita, 475 U.S. at 576.

234. Twombly, 550 U.S. at 554, 560, 561 n.7 (citing Matsushita).

235. See supra note 232.

236. See generally Tellabs, 551 U.S. 308.

237. See id. at 313-14.

238. See id. at 314.

239. It is also somewhat difficult to determine why the PSLRA is necessary if Twombly's plausibility analysis also requires a probability analysis. One theory is that the PSLRA requires a probability analysis in a particular type of case that would not be subject to a probability analysis under Twombly. As I have previously explained, I believe that Twombly's plausibility analysis is only triggered by a complaint that fails the factual specificity requirement of Rule 8 of the Federal Rules of Civil Procedure. Under the PSLRA, a judge considers the probability that the defendant acted with scienter. See id. at 313-14. I do not believe this is the type of complaint that would be subject to Twombly's plausibility analysis because it is impossible to describe a defendant's scienter with factual specificity. Scienter is a fact, but it is not a real world event that can be described with any more specificity than the simple allegation that the "defendant acted with scienter."

Another theory is that the PSLRA is necessary because it requires a higher standard of probability than that required under Twombly. A few commentators have advanced this theory. See, e.g., Jason Bartlett, Into the Wild: The Uneven and Self-Defeating Effects of Bell Atlantic v. Twombly, 24 St. John's J. Legal Comment. 73, 87 \& n.97, 88 \& n.98 (2009) (analyzing both Twombly and Tellabs in terms of probability but concluding that the Tellabs standard must be slightly more demanding than the Twombly standard).

There is also a practical explanation as to why Congress would enact a probability requirement within the PSLRA even though a probability requirement is imposed under the generic pleading rules: Congress was not aware, when it passed the PSLRA in 1995, that the Federal Rules required a probability analysis because the Court did not invent this 
assumed that both Twombly and Tellabs impose the same general pleading standard, ${ }^{240}$ but the failure of the Court to acknowledge this similarity undermines the notion that the two cases involve the same probability analysis.

That the Twombly Court meant Matsushita plausibility rather than Tellabs plausibility is further strengthened when one considers Iqbal. Despite this ambiguity regarding Iqbal's application of the plausibility standard, it is significant that the opinion fails to cite Tellabs. ${ }^{241}$ Iqbal cites Twombly, and Twombly only, on this point. ${ }^{242}$ Thus, looking collectively at the four Supreme Court cases (Matsushita, Twombly, Tellabs, and Iqbal) in which "plausibility" is most prevalently used, a pattern emerges. Tellabs uses the term "plausibility" as a term of probability. ${ }^{243}$ But, Tellabs does not cite, nor is it cited by, the other three cases. ${ }^{244}$ On the other hand, Iqbal relies on and cites Twombly. ${ }^{245}$ Twombly relies on and cites Matsushita, and Matsushita uses "plausibility" to refer to a confidence analysis. ${ }^{246}$ In this group of four "plausibility" cases, Matsushita, Twombly, and Iqbal are connected even though they involve different litigation stages (pleading and summary judgment) and different types of disputes (antitrust and discrimination). Tellabs stands alone. In trying to determine whether Twombly's (and, for that matter, Iqbal's) use of "plausibility" meant probability or confidence, the fact that Twombly is linked to Matsushita and not Tellabs is telling.

requirement until 2007, in Twombly. See Twombly, 550 U.S. at 544; 15 U.S.C. $\S 78$ u-4 (2012) (amend Dec. 22, 1995). Numerous commentators have advanced the argument that Twombly changed the rules of pleading in a way that was inconsistent with prior Supreme Court holdings. See, e.g., Miller, supra note 8, at 15-16. Although I have argued that Twombly can be completely reconciled with preexisting Supreme Court precedent (including Conley v. Gibson) regarding the introduction of the plausibility standard, I also believe it is fair to conclude that Congress could not have anticipated the plausibility standard as an element of Rule 8. See Meier, supra note 5, at 732-33. It stands to reason, then, that if Congress could not have anticipated the standard, it would also not have anticipated that this standard would be interpreted as a probability requirement. Thus, if Twombly is interpreted as a probability requirement, Congress would probably not have recognized this when it passed the PSLRA.

240. See Burbank, supra note 117, at 551-52 (discussing the Twombly and Tellabs pleading standards as if both involve the same general type of inquiry and considering the "ridiculous" notion that Twombly's standard "is more demanding than the standard under the PSLRA"); Nathan Paulich, Pleading Scienter: How Tellabs Changed Securities Class Action Litigation, 9 Fla. ST. U. Bus. REv. 127, 140 (2010) (recognizing the view that Tellabs essentially replicates the analysis from Twombly); Steinberg \& Gomez-Cornejo, supra note 8 , at 32 (discussing the "convergence of pleading standards" between Twombly and the PSLRA); Honorable Colleen McMahon, The Law of Unintended Consequences: Shockwaves in the Lower Courts After Bell Atlantic Corp. v. Twombly, 41 Suffolk U. L. REV. 851, 864-65 (2008) ("[T]here is no reason to think that 'plausible' means anything different in Twombly than it does in Tellabs.").

241. See generally Ashcroft v. Iqbal, 556 U.S. 662 (2009).

242. See id. 669-70.

243. See supra note 117.

244. See generally Tellabs, 551 U.S. 308.

245. See Iqbal, 556 U.S. at 669-70.

246. See supra notes $14 \& 234$ and accompanying text. 


\section{The Seventh Amendment}

Perhaps the most compelling reason to interpret Twombly's plausibility analysis as a confidence analysis is that a confidence analysis does not encroach, or even threaten, the right to a jury trial under the Seventh Amendment. ${ }^{247}$ The core of the Seventh Amendment is the jury's right to decide disputed questions of fact: "[t]he limitation imposed by the amendment is merely that ... the ultimate determination of issues of fact by the jury be not interfered with." 248 Under a confidence analysis, the jury's territory is preserved because, under a confidence analysis, a judge does not make any determination regarding the existence or non-existence of the facts in dispute. ${ }^{249}$ Instead, a judge makes a decision about whether the evidence is adequate so as to allow a jury to make a decision. ${ }^{250}$ Importantly, the judge's decision as to whether to allow the case to proceed is not based on the judge's own views of the probative value of the record evidence. ${ }^{251}$ Instead, the judge's decision under a confidence analysis is based on the quantity of the evidence that is available. ${ }^{252}$

In this sense, then, a confidence analysis is analytically similar to other procedural decisions by a judge that do not violate the Seventh Amendment. For instance, under Rule 403 of the Federal Rules of Evidence, a judge has to determine whether relevant evidence must be excluded because "its probative value is substantially outweighed by a danger of ... unfair prejudice, confusing the issues, misleading the jury, undue delay, wasting time, or needlessly presentating of cumulative evidence." 253 The application of this rule requires a trial court judge to make decisions about the usefulness of particular pieces of evidence to the jury's decision-making process. ${ }^{254}$ This managerial power, however, is not usually considered a violation of the Seventh Amendment ${ }^{255}$ because the "ulti-

247. See U.S. Const. amend VII.

248. In re Peterson, 253 U.S. 300, 310 (1920).

249. See Meier supra note 11, at 17-18.

250. See id. at 17.

251. See id. at $17-18$

252. See id.

253. FED. R. Evid. 403.

254. See Daniel J. Capra, The Daubert Puzzle, 32 Ga. L. Rev. 699, 778 (1998) (discussing how Rule 403 requires trial judges to determine the usefulness of relevant evidence to the jury).

255. But see Kenneth S. Klein, Why Federal Rule of Evidence 403 is Unconstitutional, and Why That Matters, 47 U. Rich. L. Rev. 1077, 1082 (2013) (arguing that Rule 403 violates the Seventh Amendment because juries, not judges, "decide what weight to give [to] evidence"). Although Professor Klein's arguments are well presented, I believe that he has erred in describing the gist of the Seventh Amendment as the jury's right to weigh evidence. Rather, as the Supreme Court has stated, "[t]he limitation imposed by the amendment is merely that ... the ultimate determination of issues of fact by the jury be not interfered with." In re Peterson, 253 U.S. 300, 310. This distinction is subtle but important. Saying that a jury is protected as the ultimate decision-maker is not the same as saying that the judge has no input as to the information from which the jury must decide. To be sure, a jury must weigh the evidence in order to reach an ultimate conclusion, but it does not follow that a judge is precluded from engaging in the type of "weighing" required by Rule 403. A judge "weighing" evidence under Rule 403 is managing a trial but is not making the 
mate determination of issues of fact" 256 is still left to the jury.

An analogy illustrates the point. The task of a jury can be compared to a computer program that is designed to analyze data to reach a conclusion about the likelihood of a particular event occurring. Consider a computer program that is designed to determine the likelihood of rain at a certain time and date; the computer has a complicated matrix under which it analyzes the raw data entered into the computer (temperature, barometric pressure, wind, air fronts, humidity, etc.) to determine the likelihood of rain. The computer program's function is purely a probability analysis and in this way can be compared to the duty of a jury to determine the likelihood of particular events. Notice, however, that the computer program requires the input of raw data, and this in turn requires a decision as to what data to feed into the computer. The meteorologist relying on the computer's number-crunching ability might decide to refrain from inputting some data because of the time and expense associated with gathering this data, despite the reality that this data would slightly improve the computer's accuracy. So, for instance, a meteorologist might decide to avoid gathering the water temperature of a distant ocean or lake, even though this data would improve the accuracy of the weather prediction generated by the computer program. Along these same lines, a judge might decide (under Rule 403) to exclude some evidence from the jury as part of the judge's discretion about the cost and benefits of gathering and presenting this evidence. Notice, however, that the "ultimate determination" regarding the probability question is preserved for the jury (or the computer): the judge (or meteorologist) must decide what information to present the "fact-finder," but it is the jury (or the computer) that is left to weigh the evidence and make a probability conclusion.

Whereas a judge's evidentiary analysis can be compared to the task of deciding what input to feed into the computer, a confidence analysis is akin to a decision that there is so little information to feed to the computer that the program will not be run. Suppose a situation in which many of the meteorologist's tools for gathering raw data have broken. Thus, the only information that is available to feed into the computer is the air temperature and wind speed. The computer can perform a probability analysis based only on this limited data, but there will be little confidence in whatever prediction is given by the computer. Under this scenario, rather than allowing the computer to generate a prediction based on this scant information, the meteorologists might decide to forego the process and pull the plug on the computer. This decision is made not because the meteorologist necessarily thinks that the prediction made by the computer would be wrong - the meteorologist recognizes that the computer is adept at performing this probability calculation—but because the limited

"ultimate determination of issues of fact," which is preserved for the jury by the Seventh Amendment.

256. Peterson, 253 U.S. at 310. 
quantity of information means that there can be little confidence in the ultimate prediction. The problem is not the matrix by which the computer offers a prediction, but rather the limited information that is available to input into the calculation. Similarly, a judge who decides a case through a confidence analysis does not preempt the jury's probability analysis, but rather makes a conclusion regarding the adequacy of the information from which the jury would be expected to assess probability. The judge, figuratively speaking, pulls the plug on the jury, but not because the judge distrusts the jury's ability to assess probability.

While a confidence analysis preserves for the jury "the ultimate determination of issues of fact," 257 a probability analysis does not. When a judge resolves a case pursuant to a probability analysis, the judge has substituted her probability analysis for that of the jury. To continue with the analogy made above, a judge employing a probability analysis is akin to the meteorologist independently analyzing the data and concluding that the computer could not possibly predict rain for tomorrow. When a judge resolves a case pursuant to a probability analysis, the judge preempts the jury's constitutional role as the ultimate arbiter of the probability of disputed facts. ${ }^{258}$

The well-recognized principle that ambiguous language should not be interpreted in a manner that implicates constitutional questions works in favor of the confidence interpretation of Twombly's plausibility standard. ${ }^{259}$ Conversely, the serious constitutional questions that arise under a probability interpretation of plausibility undermine the probability perspective of Twombly. ${ }^{260}$

\section{The Policy Behind Twombly and the Transsubstantive Nature of the Federal Rules of Civil Procedure}

Earlier, the Twombly decision was analyzed in terms of what the Court said about the plausibility analysis it was applying. ${ }^{261}$ The results of that inquiry were not particularly fruitful in attempting to determine whether plausibility means probability or confidence. A broader perspective on the nature of the problem the Twombly Court was concerned with, however, confirms that the Court was using plausibility as a term of confidence rather than probability.

The first problem that seems to be driving the Court in Twombly is the notion that a "false positive[]" result in antitrust law can be particularly

257. Id.

258. See Darrell A. H. Miller, Iqbal and Empathy, 78 UMKC L. Rev. 999, 1005-06 (2010) (noting the potential constitutional problems with interpreting Twombly as requiring a probability analysis).

259. See Solid Waste Agency v. U.S. Army Corps of Eng'rs, 531 U.S. 159, 173 (2001).

260. That these constitutional concerns were discounted in Tellabs is not determinative. As explained previously, the Court's analysis in Tellabs is neither thorough nor compelling. Hopefully, the Court will soon reconsider the shoddy analysis and reasoning in Tellabs regarding the scope of the Seventh Amendment.

261. See supra notes 191-97 and accompanying text. 
harmful. ${ }^{262} \mathrm{~A}$ false positive occurs when a defendant is incorrectly determined to have committed illegal conduct. ${ }^{263}$ The problem is thought to be particularly acute in antitrust law. ${ }^{264}$ A defendant's aggressive, capitalist behavior is desirable from a market standpoint if that behavior is the result of the defendant's sole conduct. 265 If, however, a defendant's behavior is the result of an agreement or conspiracy with other market participants, that behavior constitutes a violation of antitrust law. ${ }^{266}$ Thus, the same behavior might be either desirable or illegal depending on whether it is the result of anticompetitive agreement. ${ }^{267}$ Obviously, then, the likelihood-and consequences-of a false positive result are more dramatic within antitrust law than in other contexts: a false positive in the antitrust context means that a defendant is punished for conduct that is not merely legal but also desirable. In Twombly, the Court specifically references the problem of an antitrust "false positive." 268

The other concern driving the Court's decision in Twombly is the expansive, and expensive, nature of discovery in antitrust cases. ${ }^{269}$ The plaintiff's ability to subject a defendant to massive discovery means that there is an in terrorem settlement value to the case simply because of the potential expenses to the defendant that can eliminated by a quick settlement. ${ }^{270}$ The Court viewed its decision in Twombly as addressing this question and explicitly ruled out the notion that this problem could be resolved by "judicial supervision" of the discovery process. ${ }^{271}$

Both of the issues identified by the Court in Twombly are problems from the perspective of the defendant rather than the plaintiff. And each of these problems is remediated by the imposition of either a probability

262. See Bell Atl. Corp. v. Twombly, 550 U.S. 544, 554 (2007).

263. See Mark Anderson \& Max Huffman, Iqbal, Twombly, and the Expected Cost of False Positive Error, 20 Cornell J.L. \& Pub. Pol'y 1, 1, 22 (2010) (explaining the concept of false positive errors, including settlements in which the defendant pays money to the plaintiff even though no illegal conduct occurred).

264. See id. at 22 (discussing the false positive problem in the context of antitrust law).

265. See Parker v. Brown, 317 U.S. 341, 351 (1943) (explaining that the Sherman Act's "purpose was to suppress combinations" because they "restrain competition").

266. 15 U.S.C. $\S 1$ (2012).

267. See Max Huffman, The Necessity of Pleading Elements in Private Antitrust Conspiracy Claims, 10 U. PA. J. Bus. \& EMP. L. 627, 651 (2008) ("The challenge is to distinguish those claims that are inappropriate sanctions for pro-competitive conduct-the false positives-from those that appropriately act as disincentives to harmful conduct. Courts and commentators understand that the height of competitive activity may look very much like conduct that violates Sherman One.").

268. See Bell Atl. Corp. v. Twombly, 550 U.S. 544, 554 (citing the AEI-Brookings Joint Center for Regulatory Studies, Epstein, Motions to Dismiss Antitrust Cases: Separating Fact from Fantasy, Related Publication 06-08, pp. 3-4 (2006)). The Twombly Court also references the Court's previous decision in Matsushita. See id. at 554, 560, 561 n.7 (where the Court's "false positive" concern compelled the Court to conclude that the plaintiff had not satisfied the summary judgment confidence inquiry); see also Meier, supra note 12, at 751.

269. See Twombly, 550 U.S. at 558 ("[P]roceeding to antitrust discovery can be expensive.").

270. See id. (discussing the in terrorem settlement value to a case once it moves beyond the pleadings stage); see also Anderson \& Huffman, supra note 263, at 20-21 (same).

271. Twombly, 550 U.S. at 559. 
or confidence analysis at the pleadings stage. The imposition of a probability analysis at the pleadings stage imposes an additional factfinder that the plaintiff must convince in order to win the litigation. Because the plausibility analysis works against-and not for-the plaintiff, ${ }^{272}$ a probability analysis means that this inquiry is an "all risk, no reward" proposition for the plaintiff. Requiring the plaintiff to convince this additional fact-finder of the probability of the facts alleged in the complaint (regardless of what particular standard of persuasion the judge is applying) would serve to cut down on both the "false positive" and in terrorem discovery abuse concerns identified by the Court in Twombly. Indeed, simply dismissing all antitrust complaints at the outset of litigation would completely eliminate all false positive results and all in terrorem settlements. ${ }^{273}$ Requiring a judge to perform probability at the outset of the litigation increases the likelihood of this type of dismissal and thus addresses the dual concerns driving the Court's decision in Twombly.

A confidence analysis also addresses the concerns identified by the Twombly Court. Requiring a plaintiff to come forward with additional information before he is allowed to proceed in the litigation means that the cases that are allowed to proceed might tend to be the cases in which the need for massive discovery is not as great. The more information a plaintiff has at the outset of litigation, the less need for discovery; conversely, a plaintiff with relatively little information at the outset of the case will have the greatest need for discovery. In addition, any analysis that increases the likelihood of a dismissal on the pleadings means that the potential for a false positive diminishes, assuming that at least some of the cases being dismissed are cases in which the plaintiff's factual assertions are incorrect. Requiring a confidence analysis at the pleadings stage, then, would address both of the concerns raised by the Court in Twombly.

Thus, simply identifying the policy concerns of the Court in Twombly does little to distinguish whether plausibility means confidence or probability because either analysis would help alleviate the Court's defendant-centric concerns. That said, attempting to fix these concerns

272. Some have suggested that the plausibility analysis can work for a plaintiff when the standard is applied to a defendant's pleading assertions. See, e.g., Joseph A. Seiner, Plausibility Beyond the Complaint, 53 WM. \& MARY L. REv. 987, 991-92 (2012) (arguing that the plausibility analysis should be applied to affirmative defenses raised by the defendant). Thus, it might be more accurate to say that a plausibility standard works against the party whose pleadings are being measured under the standard. A plaintiff cannot win a case by showing that her complaint is plausible; she just avoids losing the case. Similarly, a defendant does not win a case by showing that his affirmative defense is plausible; he just avoids this defense being excluded.

273. Of course, while dismissing all suits would eliminate any false positives, it would increase the amount of false negatives, situations in which a defendant avoids liability even though the defendant committed a violation. See Henry L. Chambers, Jr., Getting It Right: Uncertainty and Error in the New Disparate Treatment Paradigm, 60 Alb. L. Rev. 1, 51 (1996) ("Eliminating or reducing false positives is a reasonable goal as long as the result in not a shift in the relative proportions of false positives to false negatives."). 
through a probability analysis results in analytical problems that do not arise if plausibility instead requires a confidence analysis.

First, of course, is the Seventh Amendment issue, discussed above. A probability analysis is difficult to reconcile with the Seventh Amendment, while a confidence analysis does not raise this same policy concern. Additionally, however, a confidence analysis does a better job of squaring the antitrust-specific concerns of the Twombly Court with the transsubstantive nature of the Federal Rules of Civil Procedure. ${ }^{274}$

Both the false positive and in terrorem settlement issues are concerns that are unique to, or at least are more acute within, antitrust law. To address this problem through the application of a probability analysis seems to run afoul of the notion that the Federal Rules of Civil Procedure (Federal Rules) require the same approach regardless of the substantive nature of the case at bar. Whether a judge employs a probability analysis at the pleadings stage would seem to be an issue on which the Federal Rules would give a uniform answer. The ultimate question under a probability analysis is whether a fact exists. This same question arises, uniformly, in all different types of litigation.

If plausibility requires a confidence analysis, however, the very nature of the analysis permits a consideration of the underlying policies of a particular case while nevertheless preserving the transsubstantive nature of the Federal Rules. Recall that a confidence analysis requires a determination as to whether there is a sufficient amount of information available for the task at hand. This analysis necessarily involves a consideration of context or policy. Thus, to go back to the Royals hypothetical discussed previously, George might decide that he does have a sufficient amount of information if we slightly change the facts of the hypothetical. If George were asked to wager $\$ 1$-as opposed to $\$ 10$ - he might decide that the information he possesses is a sufficient basis on which to place a wager.

A confidence analysis at the pleading stage, then, would quite naturally consider the antitrust-specific concerns that the Court discussed in the Twombly opinion. ${ }^{275}$ As alluded to earlier in this Article, a pleadings confidence analysis could take two forms. The Court could ask whether the plaintiff has a sufficient amount of information such that the plaintiff could survive a confidence inquiry at the summary judgment stage. The Twombly Court, by discussing the "false positive" concern and citing Matsushita 276 - which employed a confidence analysis to affirm a summary judgment ${ }^{277}$ - supports this version of the pleadings confidence analysis. Alternatively, a pleadings confidence analysis could ask whether a plaintiff has a sufficient amount of evidence so as to be entitled to proceed to discovery. This approach would distinguish the pleadings confi-

274. See Jeffrey W. Stempel, Halting Devolution or Bleak to the Future: Subrin's NewOld Procedure as a Possible Antitdote to Dreyfuss's “Tolstoy Problem," 46 FLA. L. Rev. 57, 82 (1994) (discussing transsubstantive model of the Federal Rules of Civil Procedure).

275. See Twombly, 550 U.S. at 554.

276. See id.

277. See Meier, supra note 11, at 137. 
dence analysis from the summary judgment confidence analysis and leave room for the notion that a plaintiff should be allowed to use the formal discovery process to gather necessary information that the plaintiff did not have at the outset of the lawsuit. The Twombly Court's discussion of the need for a "reasonably founded hope that the [discovery] process will reveal relevant evidence" 278 supports this version of the pleadings confidence analysis.

Under either version of this pleadings confidence analysis, however, a consideration of context-including the subject matter involved in the suit-would be warranted. And, importantly, this context-specific analysis would not violate the transsubstantive nature of the Federal Rules. The confidence requirement would apply across-the-board, consistent with the transsubstantive principles of the Federal Rules. The application of this principle, however, would necessarily consider context, including the legal subject matter of the dispute. That transsubstantive rules might apply differently to different types of cases is not an unusual result. Indeed, under Rule 8, a court has to determine whether the plaintiff has alleged a violation of the law. ${ }^{279}$ The existence of this requirement is transsubstantive, but there is no way that a judge could apply this transsubstantive requirement except by considering the particular context and subject matter of the dispute.

The distinction between the existence of transsubstantive rules and context-specific applications explains why the Iqbal Court rejected the notion that Twombly's pleading standard should be limited only to antitrust cases. ${ }^{280}$ The Iqbal court made clear that the plausibility standard that was articulated in Twombly was a product of Rule 8, which applies to "all civil actions and proceedings in the United States district courts."281 That said, the Court in both Twombly and Iqbal also made clear that the antitrust and qualified immunity contexts of those cases were important. $^{282}$ The distinction between the existence of a transsubstantive rule and context-specific application of that rule explains these seemingly contradictory statements.

Distinguishing between the existence of a transsubstantive rule and the context-specific application of the rule does not work as well, however, if plausibility means probability. It is somewhat difficult to conceive of a

278. Twombly, 550 U.S. at 559-60 (quoting Dura Pharm., Inc. v. Broudo, 544 U.S. 336, $347(2005))$.

279. See Thomas D. Rowe, Jr., Suzanna Sherry, \& Jay Tidmarsh, Civil ProceDURE 60 (2004) (explaining the need for a judge to determine the legal merits of the plaintiff's complaint as a "substantive sufficiency" challenge).

280. See Ashcroft v. Iqbal, 556 U.S. 662, 684 (2009).

281. Id. (quoting Fed. R. Civ. P. 1).

282. See id. at 675 ("In Twombly, the Court found it necessary first to discuss the antitrust principles implicated by the complaint. Here too we begin by taking note of the elements a plaintiff must plead to state a claim of unconstitutional discrimination against officials entitled to assert the defense of qualified immunity.") (internal citation omitted); see also David L. Noll, The Indeterminacy of Iqbal, 99 GeO. L.J. 117, 137 (2010) (stating that Iqbal was "plainly [] motivated by concerns originating in the law of official immunity"). 
probability standard that morphs depending on the context of the dispute. ${ }^{283}$ If Twombly requires probability, the seeming import of the antitrust and qualified immunity contexts in Twombly and Iqbal would apparently require a court's benchmark for determining probability to rise. Thus, for instance, a judge could apply a $40 \%$ probability standard in an antitrust or qualified immunity case but only a $15 \%$ standard in a typical case in which there are not the same false positive and in terrorem concerns. Nothing about the nature of a probability inquiry, however, would seem to permit a court to massage the standard based on these context-specific concerns. A probability analysis is about the ultimate existence of facts. The likelihood of a material fact does not depend on context or policy. As such, manipulating these standards based on policy concerns seems to run afoul of the transsubstantive nature of the Federal Rules. To require a judge to employ a higher burden of persuasion is not simply an instance in which the rule applies differently depending upon context. Requiring a higher standard of probability for particular types of cases (such as antitrust and qualified immunity) is to apply a completely different rule. ${ }^{284}$ This violates the transsubstantive principles within the Federal Rules.

\section{CONCLUSION: HOW A CONFIDENCE ANALYSIS COMPLEMENTS RULE 8'S FACTUAL SPECIFICITY REQUIREMENT}

As discussed above, an interpretation of Twombly's plausibility standard as involving a confidence analysis is thus superior-on multiple levels-to a probability interpretation of the standard. A final argument in favor of a confidence reading of Twombly's plausibility standard, advanced in this section, is that this reading of the standard facilitates a cohesive and sensible understanding of the entire pre-trial process. In particular, interpreting Twombly's plausibility standard to require a confidence analysis aligns plausibility with the traditional requirement that a complaint include a certain level of factual specificity in order to avoid dismissal. The factual specificity requirement, properly understood, is a form of confidence analysis and serves as a trigger for the plausibility test;

283. Professor Kaplow has suggested an interpretation of the plausibility standard that allows a judge to apply a different standard of probability based on the type of suit involved and relevant policy considerations regarding allowing the case to proceed. See generally Kaplow, supra note 43, at 1252-83. I believe that the thesis advanced in this Article originates from roughly the same perspective as that of Professor Kaplow. That said, his sliding-scale probability interpretation of plausibility does not account for the transsubstantive nature of the Federal Rules. See id. Moreover, Professor Kaplow does not consider how his proposed understanding of Twombly fares under the Seventh Amendment. See id. at n.177 (admitting that he has pushed the constitutional issues "to the side"). In my opinion, these issues simply cannot be ignored in attempting to construct a doctrinal basis for the plausibility analysis.

284. The PSLRA demonstrates this concept. The probability analysis of the PSLRA violates the transsubstantive principles of the Federal Rules but it does so through the adoption of a different rule. See Tellabs, Inc. v. Makor Issues \& Rights, Ltd., 551 U.S. 308, 313 (2007) (explaining the special requirements of the PSLRA). 
it only makes sense that the plausibility test would require the same type of analysis as that involved under the factual specificity requirement. This conclusion follows from the logical progression of steps outlined below.

Step 1: Factual Specificity is a Pleading Requirement Under the Federal Rules of Civil Procedure

The requirement of factual specificity 285 in a complaint has a long history within American jurisprudence, and the standard for what is required has ebbed and flowed during particular periods. ${ }^{286}$ The enactment of the Federal Rules clearly represented a commitment to a more relaxed standard of factual specificity, ${ }^{287}$ but the Federal Rules did not completely eliminate the factual specificity requirement. ${ }^{288}$ A plaintiff's complaint must include at least a minimum amount of factual specificity regarding the events on which the defendant's liability is premised in order to satisfy the requirements of Rule 8.

Step 2: The Pleading Requirement of Factual Specificity Is an Implicit Requirement for Evidence

A factual specificity requirement is not a measure of the drafting ability of the plaintiff's lawyer. Instead, it is an implicit requirement regarding the evidence a plaintiff must have at the outset of the suit. As Professor Kaplow has stated:

[I]nsistence on a statement of facts (notably, regarding allegations in a complaint) does not in itself constitute a demand for evidence. . . . This conclusion, however, is substantially misleading - that is, as long as allegations based on pure fantasy are impermissible. Proffering a fact entails holding some basis for acceptance of the fact as true, which in turn requires possessing some evidence. . . Knowledge presupposes some evidentiary basis, information is tantamount to evidence, and belief in the truth of a fact presupposes evidence. As a consequence, although insistence on particular facts is not per se a demand for evidence, for all practical purposes it requires evidence. ${ }^{289}$

Properly understood, then, the factual specificity requirement is not really about the skill of the lawyer in drafting the complaint, but rather the

285. A variety of terms other than "factual specificity" has been used to refer to the requirement that a complaint contain a minimum amount of factual detail regarding the real world events on which the defendant's liability is premised. See Meier, supra note 5, at 721-22 (discussing the different words or phrases used to refer to this requirement but ultimately settling on the "factual specificity" phrase as the best).

286. See id. at 713-20 (discussing the ebb and flow regarding the amount of factual specificity required of a plaintiff's complaint).

287. See 5 Charles Alan Wright \& Arthur R. Miller, Federal Practice and Procedure $\$ 1202$, at 93 (3d ed. 1994) ("Federal civil pleadings differ from the 'fact pleading' of the codes principally in the degree of generality with which the elements of the claim may be stated.").

288. See Bell Atl. Corp. v. Twombly, 550 U.S. 544, 555 n.3 (refuting the notion that the "Federal Rules somehow dispensed with the pleading of facts altogether"); Meier, supra note 5, at 720-23 (discussing how the case of Conley v. Gibson affirms that some factual specificity is still required under the Federal Rules).

289. Kaplow, supra note 43, at 1260-61. 
evidence available to that lawyer at the outset of the litigation. A lawyer who has the right type of evidence will be able to draft her complaint with sufficient factual specificity. The real problem for a lawyer in meeting the factual specificity requirement of the Federal Rules is when there is a dearth of evidence at the time the complaint is being written.

Step 3: A Plaintiff With Direct Evidence Will Satisfy the Factual Specificity Requirement

So, what type of evidence will enable the plaintiff's lawyer to comply with the factual specificity requirements of the Federal Rules? As it turns out, the particular type of evidence a plaintiff has at the outset of a case will influence the manner in which the complaint is drafted and whether that complaint can be drafted with factual specificity.

Recall the distinction made earlier in this Article between direct and circumstantial evidence. ${ }^{290}$ If a plaintiff has direct evidence (such as a witness's account of the events) of the underlying events, she will be able to draft her complaint with factual specificity. A plaintiff who has a direct witness to the litigation events will be able to describe those events (based on the witness's account) by supplying the "who, what, when, where" regarding those events. A plaintiff who has this type of evidence will thus easily satisfy the factual specificity requirements of Rule 8 and will be allowed to proceed in the litigation (assuming the legal theory of her case is sound $)^{291}$ towards a conclusion as to whether that evidence actually represents the historical facts.

Step 4: A Plaintiff Without Direct Evidence Cannot Draft a Factually Specific Complaint

Although a plaintiff with direct evidence will have no problem drafting a factually specific complaint, a plaintiff without direct evidence simply cannot draft a factually specific complaint. Without a witness to observe the litigation facts, a plaintiff's attorney cannot describe these events in any detail. ${ }^{292}$

Step 5: A Plaintiff Without Direct Evidence Will Allege Circumstantial Evidence

When a plaintiff does not have direct evidence and thus cannot describe the material facts with factual specificity, the plaintiff's lawyer will intuitively understand that there must be some basis for making a factual assertion to which the plaintiff has no witness. In this situation, the plaintiff will explain in the complaint the foundation for the plaintiff's factual assertion that the relevant event did, in fact, occur. In doing so, the plaintiff's attorney will describe (with specificity) other facts (to which there are first-hand observers) that supply the basis of the plaintiff's conclusion

290. See supra Section I.A.

291. See Meier, supra note 5, at 722 (explaining the requirement that the facts alleged by the plaintiff represent a viable legal theory of recovery).

292. A plaintiff's attorney could, of course, fabricate specific facts regarding the events on which the defendant's liability is premised, but this would run afoul of Rule 11 of the Federal Rules of Civil Procedure. See FED. R. Civ. P. 11(b)(3) (explaining the requirement that the factual contentions in a complaint have evidentiary support). 
that the material fact did occur. In other words, the plaintiff will plead her circumstantial evidence.

The Twombly complaint illustrates this phenomenon. In Twombly, the plaintiffs needed to show the defendants had entered into an actual agreement or conspiracy. ${ }^{293}$ The plaintiffs, however, had no witness to this purported agreement and thus were unable to provide any factual detail regarding the specifics of this agreement (where it was agreed to, and when, and by whom, etc.). ${ }^{294}$ The plaintiffs' complaint attempted to justify the factual assertion of an agreement, however, by pleading (with factual specificity) the parallel business behavior of the defendants. ${ }^{295}$ In Twombly, the Court considered how to analyze a complaint that fails the test for factual specificity and, instead, asserts direct evidence of circumstantial facts from which the material fact might be inferred. 296

Step 6: A Complaint That Fails the Test for Factual Specificity Must Satisfy the Plausibility Test

In Twombly, then, the Court was presented with a dispute in which the plaintiffs (as evidenced by the plaintiffs' complaint) had no direct evidence on a material fact but, rather, only circumstantial evidence. ${ }^{297}$ The plausibility standard is the test that the Court used to measure the sufficiency of this complaint. In this sense, then, it is accurate to say that the plausibility test is triggered by the failure of a complaint to meet the factual specificity requirements of the Federal Rules. Moreover, because direct evidence always satisfies the factual specificity requirement, it is also accurate to say that the plausibility test will only be triggered by a complaint in which there is no direct evidence on a material fact. ${ }^{298}$

Step 7: Plausibility Measures the Link between the Circumstantial Evidence and the Material Fact

The plausibility analysis, then, considers the relationship between the circumstantial "evidence" pleaded by the plaintiff in her complaint (with sufficient factual specificity, meaning that the plaintiff has direct evidence regarding this fact) and the material fact to which there is no direct evidence.

If plausibility measures the relationship between the circumstantial evidence and the material fact, is this done from the perspective of probability or confidence? The progression of the analytical steps outlined above strongly suggests that plausibility involves a confidence analysis. After all, the analysis that precipitates the plausibility standard is

293. See Twombly, 550 U.S. at 546 (citing Sherman Act $\S 1$ ).

294. Id. at 551 (quoting II 51 of the plaintiffs' complaint).

295. See id.

296. See id. at 571.

297. See id.

298. This is not to say, however, that that absence of direct evidence will necessarily trigger the plausibility test. As I have explained at length elsewhere, certain factual matters are not capable of a factually specific description and thus cannot be subject to the factual specificity requirement. See Meier, supra note 5, at 755-61 (explaining how the material fact of the defendant's state of mind in Iqbal was not a fact that was capable of a specific factual description and thus should not have triggered the plausibility test). 
itself a type of confidence analysis. The factual specificity requirement is a test that measures whether the plaintiff has direct evidence at the outset of the case. This test measures the type of evidence that is present at the outset of the case, but it has nothing to do with the ultimate truth of that direct evidence. The factual specificity requirement is about the sufficiency of evidence but not about the ultimate "truth" or probability of facts. This factual issue is resolved later in the lawsuit. Thus, to the extent that the factual specificity requirement is a conclusion about the adequacy of the evidence put forward by the plaintiff, but not the ultimate facts of the litigation, it is a form of a confidence analysis.

Because the factual specificity requirement is a legal analysis regarding the adequacy of evidence rather than the existence of facts, it is only logical that the plausibility test, which is triggered by the factual specificity requirement, would also involve this same type of inquiry. Indeed, it would be somewhat ironic to ask a judge to do a probability analysis of a plaintiff's circumstantial evidence simply because the plaintiff had failed the factual specificity analysis. This is akin to asking a student who has failed her Latin exam to retake the exam, but then asking her about calculus-rather than Latin-on the retake. Regardless of how the student does on the calculus retake, we have still not resolved whether she knows her Latin. A confidence analysis and the probability analysis involve different types of inquiry, and it makes no sense to relax the requirements for the evidence a plaintiff must have at the outset of a case (a confidence inquiry) simply because a particular trial judge happens to believe in the ultimate truth of the plaintiff's version of the facts. ${ }^{299}$

There is another benefit to interpreting the plausibility test as requiring a confidence analysis. In addition to aligning the plausibility test with the factual specificity requirement, a confidence interpretation of plausibility aligns this pleading requirement with the standard for summary judgment. Numerous commentators have viewed the plausibility requirement as a pre-discovery application of the standard for summary judgment. ${ }^{300} \mathrm{I}$

299. Of course, with regard to direct evidence, it is easier to distinguish between a confidence and probability analysis because it is not possible to truly engage in a probability analysis without hearing the witnesses testify, in open court, and be subjected to cross examination. This is why, at the pleadings stage, the factual specificity requirement (a confidence inquiry) has never been mistaken as a test that requires the judge to evaluate the ultimate truth (a probability inquiry) of the plaintiff's allegations. This type of probability analysis is simply not possible from written assertions based on direct witness observations. As explained in Section III(A), however, it is possible to engage in a probability analysis of circumstantial evidence, at least when the existence of the basic facts is agreed upon by both parties. In this instance (which is the case when Twombly's plausibility analysis applies), a probability analysis depends on an estimation as to the frequency with which the material facts follow from the basic facts, but it does not depend upon proceedings in open court. Simply because a probability analysis is possible in the Twombly context (meaning cases in which the plaintiff has used circumstantial "evidence" in support of material facts to which the plaintiff has no direct witness), does not mean that this is what plausibility requires. That a probability analysis is possible in the Twombly context has contributed, I believe, to the confusion over what is actually required by the test.

300. See, e.g., Hillel Y. Levin, Iqbal, Twombly, and the Lessons of the Celotex Trilogy, 14 Lewis \& Clark L. Rev. 143, 148 (2010) (arguing that both summary judgment and 
agree with this perspective, but the true link between these two legal tests is the confidence inquiry. As I have written at length elsewhere, ${ }^{301}$ a judge applying the modern test for summary judgment will determine whether the plaintiff has produced an adequate amount of information such that the judge is justified in sending the case to the jury. The pleading requirement of plausibility requires the judge to apply this same type of inquiry at the outset of the litigation. It is not an accident that the plausibility standard was introduced in a type of case (antitrust) in which the Supreme Court had previously used a confidence inquiry to dispose of a plaintiff's claim at summary judgment (Matsushita Electric Industrial Co. v. Zenith Radio Corporation ${ }^{302}$ ). Under Matsushita, the plaintiff's circumstantial evidence was not adequate to permit the plaintiff to proceed to the jury; in Twombly, the Court simply applied this evidentiary standard to the information that the plaintiff had at the outset of the case. ${ }^{303}$

Properly understanding Twombly's plausibility standard does not mean that one has to like it; conversely, however, resolving that one does not like it should only be done after one fully understands the contours of the analytical inquiry required under the standard. Along these lines, the objective of this Article has been descriptive rather than normative. The best reading of Twombly's plausibility standard is that it requires a judge to measure the adequacy of the evidence possessed by the plaintiff at the outset of the case by using a confidence inquiry similar to the one employed by courts at the summary judgment stage. Recognizing this aspect of the confidence inquiry does not resolve all of the normative attacks that have been launched against plausibility. For instance, many of the critiques of plausibility have denounced the fact that the standard deprives the plaintiff of the opportunity to use the broad discovery tools under the Federal Rules. ${ }^{304}$ This criticism of the plausibility standard is on-target and well-founded. After all, the effect of the Court's disposition in Twombly deprived the plaintiff of the opportunity to use discovery to

modern pleadings doctrine perform a similar gatekeeping function); Lee Goldman, Trouble for Private Enforcement of the Sherman Act: Twombly, Pleading Standards, and the Oligopoly Problem, 2008 BYU L. REv. 1057, 1089 (2008) (comparing summary judgment standards and pleading standards in antitrust cases); Lonny S. Hoffman, Burn Up the Chaff With Unquenchable Fire: What Two Doctrinal Intersections Can Teach Us About Judicial Power Over Pleadings, 88 B.U. L. Rev. 1217, 1241 (2008) ("Twombly has been said to be the Matsushita of pleading."); Richard A. Epstein, Bell Atl. v. Twombly: How Motions to Dismiss Become (Disguised) Summary Judgments, 25 WAsH. U. J.L. \& PoL'Y 61, 62 (2007) ("Twombly [] was a disguised motion for summary judgment . . . .").

301. See generally Meier, supra note 12, at 814-16.

302. Matsushita Elec. Indus. Co. v. Zenith Radio Corp., 475 U.S. 574 (1986). Many commentators have noted the potential link between Twombly and Matsushita. See Burbank, supra note 117, at 559 (discussing the "striking resemblance" between Twombly and Matsushita); see also Edward Brunet, The Substantive Origins of "Plausible Pleadings": An Introduction to the Symposium on Ashcroft v. Iqbal, 14 Lewis \& Clark L. Rev. 1, 3-10 (2010) (discussing Twombly and Matsushita's joint use of the term "plausible"). But see Richard A. Epstein, Of Pleading and Discovery: Reflections on Twombly and Iqbal with Special Reference to Antitrust, 2011 U. ILl. L. Rev. 187, 197 (2011) ("Twombly involved a somewhat different fact pattern than Matsushita.").

303. See Matsushita, 475 U.S. at 597-98; Twombly, 550 U.S. at 558.

304. See supra note 32. 
locate direct evidence that might enable the plaintiff to meet the Matsushita summary judgment confidence standard. Whether a pre-trial procedural system should require the plaintiff to come armed to the litigation with a sufficient amount of evidence to proceed to a jury is admittedly a difficult normative question. This Article offers no position on that question.

That said, recognizing that plausibility requires a confidence analysis does resolve many of the critiques that have been lodged against the standard. There is a logical basis to the plausibility standard, as it is simply a logical extension of the factual specificity requirement, which is itself a form of confidence analysis. The plausibility analysis can be performed at the pleadings stage. Moreover, plausibility (properly understood as a confidence requirement) does not intrude upon the Seventh Amendment. Recognizing these aspects of the plausibility analysis will be a good start towards a better understanding of this pleading requirement, which should facilitate a discussion of the legitimate normative questions involving plausibility that this Article does not address. 
